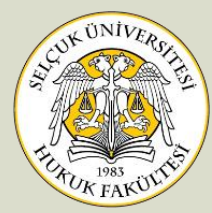

\title{
IPTAL DAVASINDA “MENFAAT İHLALİ” KOŞULU VE MENFAAT KAVRAMININ YORUMLANMASI
}

\author{
Arş. Gör. Burcu ERDİNÇ*
}

\section{Öz}

Menfaat ihlali, iptal davasına özgü bir ehliyet şartıdır. Hukuk devleti ilkesinin gerçekleştirilmesinin en mühim araçlarından olan iptal davasının sübjektif ehliyet koşulunu ifade etmektedir. Yargı kararlarına göre, menfaat ihlalinin gerçekleşebilmesi için, söz konusu menfaatin meşru, güncel ve kişisel olması gerekir. Diğer iki niteliğe göre sübjektif olan kişisel olma niteliği, yargı kararlarında menfaat ihlali kavramının kapsamını farklılaştırmakta ve belirli menfaat süjelerinin ortaya çıkmasına yol açmaktadır. Çalışmanın ilk bölümünde hukuk devleti ve iptal davası kavramları incelenmektedir. İkinci bölümünde ise, menfaat kavramının hak kavramı ile karşılaştırması yapılmakta ve yargı içtihatlarıyla belirlenen nitelikleri ortaya konulmaktadır. Özellikle kişisel olma niteliğine göre yargı kararlarıyla ortaya konan menfaat süjeleri ve grupları incelenmektedir.

\section{Anahtar Kelimeler}

Menfaat • Hukuk Devleti İlkesi • İptal Davası • Menfaatin Kişisel Olması • Menfaat Süjeleri ve Grupları

* Arş. Gör., İnönü Üniversitesi Hukuk Fakültesi, İdare Hukuku Anabilim Dalı, Malatya, Türkiye | Asst., Inonu University, Faculty of Law, Department of Administrative Law, Malatya, Turkey.

凹 burcu.erdinc@inonu.edu.tr • ORCiD 0000-0003-4103-0321

Atıf Şekli | Cite As: ERDİNÇ Burcu, "İptal Davasında Menfaat İhlali Koşulu ve Menfaat Kavramının Yorumlanması", SÜHFD., C. 29, S. 2, 2021, s. 1079-1125.

Intihal | Plagiarism: Bu makale intihal programında taranmış ve en az iki hakem incelemesinden geçmiştir. I This article has been scanned via a plagiarism software and reviewed by at least two referees. 


\title{
THE CONDITION OF "INFRINGEMENT OF INTERESTS" IN THE ANNULMENT SUIT AND INTERPRETATION OF THE CONCEPT OF INTEREST
}

\begin{abstract}
Infringement of interests are competence stipulations unique to the annulment suit. The annulment suit, which is one of the most important vehicles in the realization of the principle of the legal state, expresses the subjective competence stipulation. According to court decisions, the subject interest must be legal, current and personal to realize the infringement of interests. According to the other two attributes, the attribute of being personal, which is subjective, undergoes a change in scope of the infringement of interests in the court decisions and paves the way for the emergence of specific interest subjects. The legal state and the annulment suits are examined in the first section of study. Whereas, in the second section, a comparison is made between interest and right and its attributes are set forth that determine the judicial precedents. Especially, the interest subjects and groups are examined according to the attribute of being personal.
\end{abstract}

\section{Key Words}

Interest • Principle of Legal State • Annulment Suit • Personal Interest • Interest Subjects and Groups

\section{GİRIŞ}

İdari rejimi benimseyen Türkiye Cumhuriyeti, bir hukuk devletidir. Bu sebeple, idarece yapılan tüm eylem ve işlemlerin hukuka uygun olması gerekmektedir. Hukuka uygun olmayan işlem ve eylemlerin tespit edilebilmesi için denetlenebilir olmaları şarttır.

1982 Anayasası'nın 125. maddesi, hukuk devleti ilkesinin güvence hükümlerindendir. Maddede, idarenin her türlü eylem ve işlemine karş1, yarg1 yolunun açık olduğu ifade edilmiştir. Hukuk devleti ilkesinin güvencesi olan idarenin yargısal denetimi açısından değerlendirdiğimizde, iptal davası büyük önem arz etmektedir. Hukuka aykırı olduğu iddia edilen idari işleme karşı açılan iptal davasının uygulama alanı ne kadar geniş olursa, hukuk devleti ilkesi de o ölçüde güvence altında olur. İptal davasının sübjektif ehliyet şartı olan menfaat ihlalinin kapsami, doğrudan kimlerin hangi durumlarda menfaat süjesi kabul edilebileceğiyle, dolaylı olarak ise hukuk devleti ilkesiyle ilişkilidir. Menfaat kavramı, kişilerin dava konusu işlemle aralarındaki ciddi ve makul bir 
alakadan ibarettir. Tam yarg1 davalarında aranan kişisel hak ihlali gibi bir ehliyet şartı değildir. İptal davalarında daha esnek bir ehliyet şartının aranmış olması, kavramın hukuk devleti ilkesiyle sıkı ilişkisini ortaya koymaktadır.

\section{IDARENIN DENETLENMESİ BAĞLAMINDA HUKUK DEVLETI İLKESI VE İPTAL DAVASI}

\section{A. HUKUK DEVLETI İLKESI}

\section{Tanımı}

Hukuk devleti, devletin hukuk kurallarına göre yönetildiği; keyfi kurallara göre yönetilmediği devlet rejimini ifade etmektedir. ${ }^{1} \mathrm{Bu}$ rejimin temel özelliği, devletin faaliyetlerinde hukukla bağlı olmasıdır. Mülk devlet ve polis devletinin ${ }^{2}$ aksine, hukuk devletinde esas olan kişilerin değil, hukukun üstünlügüüur. Bu nedenle, idarenin tüm faaliyetlerinin hukuka uygun olması gerekir.

Anayasa Mahkemesi'nin bir kararında ${ }^{3}$ belirtildiği üzere, hukuk devleti, her alanda adaletli bir hukuk düzeni kurmayı ve kanunların

1 Hukuk devletine ilişkin detaylı bilgi için bkz. GÜNDAY, Metin, İdare Hukuku, İmaj Yayınevi, 10. Baskı, Ankara, 2013, s. 37 vd; ATAY, Ender Ethem, İdare Hukuku, Turhan Kitabevi, 6. Baskı, Ankara, 2018, s. 87 vd; AKYILMAZ, Bahtiyar/SEZGİNER, Murat/KAYA, Cemil, Türk İdare Hukuku, 12. Baskı, Savaş Yayınevi, Ankara, 2020, s. 75 vd; ŞENOL, Coşkun, “İptal Davalarında Menfaat İhlali Koşulu", Terazi Hukuk Dergisi, Yı1 5, Sayı 46, 2010, s. 139; ÇAĞLAYAN, Ramazan, İdare Hukuku Dersleri, Adalet Yayınları, 7. Baskı, 2019, s. 100 vd.

2 Hukuk devleti öncesinde var olan Mülk devlet ve Polis devlet anlayışlarında hukukun üstünlüğü yerine farklı kavramlar esas alınmıştır. Mülk devlette insan hak sahibi bir birey olarak görülmediğinden, Hükümdar istediği gibi kişiler üzerinde de tasarrufta bulunabilmiştir. Hükümdarın uymak zorunda olduğu hukuk kurallarından bahsedilemez. Hükümdar sadece diğerlerinin uyacağı kuralları belirler. Polis devlet anlayışı, Mülk devlet anlayışından farklı olmakla birlikte, yine hükümdarın hiçbir hukuk kuralıyla bağlı olmadığı bir devlet anlayışını ifade etmektedir. Mülk devletten farkı, hükümdarın üstün yetkilerini kendi varlığından değil, temsil ettiği Devletten almasındadır. Mülk devlet ve Polis devlet, devleti yönetenlerin keyfi hareket ettikleri, kişi hak ve özgürlüklerinin önemsiz olduğu rejimlerdir. Ayrıntılı bilgi için bkz. GÜNDAY, s. 37 vd; ATAY, İdare, s. 91 vd; AKYILMAZ/SEZGİNER/KAYA, İdare, s. 75 vd.

3 “...tüm işlem ve eylemlerinin hukuk kurallarına uygunluğunu başlıca gerçeklik koşulu bilen, her alanda adaletli bir hukuk düzeni kurmayı amaçlayan ve bunu geliştirerek sürdüren, hukuku tüm devlet organlarına egemen kılan, Anayasa'ya aykırı durum ve tutumlardan kaçınan, insan haklarına saygı duyarak bu hak ve öz- 
üzerinde kanun koyucunun etki edemeyeceği temel hukuk ilkeleri, insan hakları ve Anayasa hükümlerinin olduğunu; idarenin her türlü işlem ve eyleminin hukuka uygun olması gerektiği gerçekliğini vurgulayan devlettir. Danıştay'ın, Anayasa Mahkemesi'ne atıf yaptığı tanımlamasına ${ }^{4}$ göre; Cumhuriyetin niteliklerinden olan hukuk devleti ilkesi, devletin işlevlerini yerine getirirken hukuk kurallarına bağlı olduğu ve vatandaşların hukuki güvenliğe sahip oldukları bir sistemdir. Anayasa Mahkemesi'nin de belirttiği üzere, hukuk devleti, insan haklarına sayg1lı, insan haklarını koruyacak âdil bir hukuk düzeni kuran ve sürekliliğiyle kendisini yükümlü sayan ve nihayetinde bütün eylem ve işlemleri yargisal denetime tabi olan devlettir. ${ }^{5}$

Nihayetinde, hukuk devleti, devletin tüm organlarının işlem ve eylemlerini hukuk kurallarına uygun olarak yaptıkları, işlem ve eylemlerine karşı yargı yolunun açık olduğu, kişiler bakımından hukuki güvenlik ve belirliliği sağlamayı amaçlayan, bu çerçevede insan onuru, adalet, eşitlik ideallerinin peşinde olan, evrensel hukuk ilkeleri, anayasa ve yasaların üstünlüğünü kabul eden, temel hak ve özgürlüklere saygılı, kuvvetler ayrılı̆̆ını, mahkemelerin bağımsızlığını, idarenin kanuniliğini ve devletin işlem ve eylemlerinden sorumluluğunu esas alan devlettir.

gürlükleri koruyup güçlendiren, Anayasa ve hukuk kurallarına bağlılığa özen gösteren, yargı denetimine açık olan, yasaların üstünde yasa koyucunun da bozamayacağı temel hukuk ilkeleri ile Anayasa'nın bulunduğu bilincinden uzaklaşmayan devlettir." AYM'nin 06.07.1995 tarih ve E.1994/80, K.1995/27 sayılı kararı, RG. 02.02.1996-22542.

4 Danıştay IDDK'nın 26.06.2008 tarih ve E.2007/1724, K.2008/1706 sayılı kararı, (Sinerji).

5 “...bütün işlem ve eylemleri hukuka uygun, her alanda adaletli bir hukuk düzeni kurup bunu geliştirerek sürdürmekle kendini yükümlü sayan, hukuku tüm devlet organlarına egemen kılan, Anayasa'ya aykırı durum ve tutumlardan kaçınan, insan haklarına dayanan, bu hak ve özgürlükleri koruyup güçlendiren, yargı denetimine açık, yasaların üstünde yasa koyucunun da uymak zorunda olduğu Anayasa'nın ve temel hukuk ilkelerinin bulunduğu bilincinde olan devlettir." Danıştay IDDK'nın 19.04.2007 tarih ve E.2007/2988, K.2007/555 sayılı kararı, (Kazanc1). Aynı yönde AYM'nin 29.11.2017 tarih ve E.2017/137, K.2017/161 sayılı kararı, RG. 19.12.201730725. 


\section{Hukuk Devleti İlkesinin Unsurları ve Özellikle İdarenin}

\section{Yargisal Denetimi}

Danıştay Genel Kurulu'nun 1978 tarihli kararında ${ }^{6}$ belirtildiği üzere, hukuk devleti, temel hakların güvenliği, kanunların genelliği ve Anayasaya uygunluklarının yargısal denetimi, idarenin hukuka bağlılığı (hukuki idare) ve yargısal denetimi, mahkeme ve hâkim bağımsızlığı, kuvvetler ayrılığı, demokratik rejim ile devletin (mali) sorumluluğu ilkelerine dayanmaktadır. Yukarıdaki başlıkta yer verilen yargı kararlarıyla birlikte değerlendirildiğinde; hukuk devleti ilkesinin, temel hak ve özgürlüklerin tanınması ve güvenceye alınması, kanunların Anayasaya uygunluğunun yargısal denetimi, idarenin yargısal denetimi, kanuni idare ilkesi, kuvvetler ayrılığı ilkesi, demokrasi, adalet, insan hakları, hukuki güvenlik ve belirlilik, mahkemelerin bağımsızlığı ve hâkimlik teminatı, idarenin mali sorumluluğu gibi unsurlardan oluştuğu görülmektedir. ${ }^{7}$

Hukuk devleti ilkesinin unsurlarından olan "idarenin yargısal denetimi", idareyi hukuka aykırı ve keyfi davranışlardan kaçınmaya ve hukuk sınırları içinde hareket etmeye zorlar. ${ }^{8}$ Devlet hukuka uygun hareket ettikçe bireyler, üstün kamu gücü kullanan devlet karşısında kendilerini güvende hissederler. Bireylere bu hukuksal güvenceyi sağlamak, devletin en temel görevlerinden biridir. İdarenin faaliyetlerini yargısal denetim dişında tutmak, hukuksal güvence gereği mümkün değildir. İdarenin hukuka bağlılı̆̆ı, hiyerarşi ve idari vesayetle sağlanan iç dene-

Danıştay Genel Kurulu'nun 28.12.1978 tarih ve E.1978/80, K.1978/76 sayılı kararı, Danıştay Dergisi, Yıl 1979, Sayı 34-35, s. 216.

7 Akyılmaz/Sezginer/Kaya, hukuk devleti ilkesinin unsurlarını maddi ve şekli unsurlar olarak ikili bir ayrımda ele almıştır. Buna göre, hukuk devleti ilkesinin şekli unsurlarının maddi içeriğini ve hukuk devletinin maddi dayanaklarını oluşturan maddi unsurlar; insan onuru, adalet, eşitlik ve özgürlüktür. Devletin kendini sınırladığı hukuk kurallarını ve müesseseleri ifade eden şekli unsurlar ise demokrasi, temel hak ve hürriyetlerin tanınması ve güvence altına alınması, kuvvetler ayrılığı ilkesi, yargı organının bağımsızlığı ve hâkimlik teminatı, hukuki belirlilik, yasama organının yargısal denetimi, yürütmenin yargısal denetimi, idarenin kanuniliği, devletin mali sorumluluğu ve hukuki güvenliktir. Bkz. AKYILMAZ/SEZGINER/KAYA, İdare, s. 79 vd.

8 GÜNDAY, s. 46; ATAY, İdare, s. 135 vd; AKYILMAZ/SEZGİNER/KAYA, İdare, s. 112. 
tim, parlamento denetimi, kamuoyu denetimi gibi diğer denetimlerle sağlanabilirse de en etkili yöntem idarenin yargısal denetimidir. ${ }^{9}$ Danıştay'ın, yargısal denetimin önemini ifade ettiği bir kararına göre; hukuk devleti ilkesinin temeli, Devletin tüm organlarının faaliyetlerinin hukuk sınırları içerisinde olup olmadığının yargısal denetimine tabi tutulmasıdır. İdari yargının ya da anayasa yargısının denetimini önleyen her kural, kişileri hukuki güvenlikten yoksun bırakır ve hukuk devleti ilkesini ihlal eder. ${ }^{10}$

İdarenin yargisal denetimi, hukuk devletinin olmazsa olmaz bir unsurudur. ${ }^{11}$ Ancak Anayasamızda bu kurala birtakım istisnalar getirildiği görülmektedir. Önce istisnasız bir kurala yer verilmiş, ardından kurala istisnalar getirilmiştir. Hukuk alanında neredeyse her kuralın bir istisnası olmakla birlikte, hukuk devleti ilkesinin gerçekleşmesini sağlayacak unsurlar bakımından istisnaların olmaması gerekir. Devletin iradesine bağlı her işlem yargısal denetime tabi olmalıdır. Çünkü idarenin yargısal denetiminin amacı, kişilerin hak ve özgürlüklerinin, idarenin hukuka aykırı faaliyetlerine karşı korunmasıdır. ${ }^{12}$ Öte yandan idarenin yargisal denetimi hak arama hürriyetinin ve adil yargılanma hakkının bir gereğidir. ${ }^{13}$

İptal davasının konusunu oluşturan idari işlemler, idare adına irade açılamaya yetkili makamlar tarafından yapılan, ilgilinin rızası gerekmeksizin hakkında hukuki sonuç doğuran icrai ve tek yanlı işlemlerdir. ${ }^{14}$ İşlemin tanımından anlaşılacağı üzere, işlemin yapılması sürecinde ilgililerin etkililiği söz konusu değildir. Bu nedenle işlem kendilerine

9 ŞENOL, s. 139.

10 Danıştay İDDK'nın 19.04.2007 tarih ve E.2007/2988, K.2007/555 sayılı kararı, (Kazanc1).

11 “...idari tasarrufların kazai murakabeye tabi tutulması, hukuka bağlı devlet prensibinin en mütebariz ve karakteristik vasfı icabındandır." Danıştay DDGK'nın 30.03.1950 tarih ve E.1949/320, K.1950/128 sayılı kararı için bkz. Danıştay Kararlar Dergisi, Sayı 50-53, s. 118.

12 GÖZÜBÜYÜK, Şeref/TAN, Turgut, İdare Hukuku Genel Esaslar Cilt I, Turhan Kitabevi, Ankara, 2013, s. 36.

13 ŞENOL, s. 140.

14 AKYILMAZ/SEZGINNER/KAYA, İdare, s. 326; GÜNDAY, s. 123 vd; DURAN, Lütfi, İdare Hukuku Ders Notları, İstanbul Üniversitesi Yayınları No: 2956, İstanbul, 1982, s. 385; YAYLA, Yıldızhan, İdare Hukuku, Beta Yayınları, İstanbul 2009, s. 108. 
tebliğ edildiğinde hukuka aykırı olduğunu düşünüyorlarsa, menfaati ihlal edilen ilgililer işlemi dava edebilirler. Çalışmamızın konusunu oluşturan menfaat kavramını geniş yorumladığımızda, idarenin yargısal denetimini uygulama alanını da genişletmiş oluruz. Bu nedenle menfaat kavramı, nihayetinde hukuk devleti ilkesine hizmet etmektedir.

İdarenin yargısal denetimine ilişkin ilk anayasal düzenleme, 1961 Anayasası'nda "Yargı Denetimi" başlı̆̆ını taşıyan 114. maddedir. İdarenin hiçbir işlem ve eyleminin hiçbir durumda yargı mercii denetimi d1şında bırakılamayacağını düzenlenmiştir. İdarenin yargısal denetimi bakımından hiçbir istisna öngörülmemiştir. ${ }^{15} 1982$ Anayasası'nda ise, "Yargı Yolu" başlıklı 125. maddeyle, istisnalar öngörülerek, 114. maddeye göre daha esnek bir düzenlemeye yer verilmiştir.

125. maddeye göre, genel kural, idarenin her türlü eylem ve işlemine karşı yargı yolunun açı olduğudur. Ancak hukuk devleti ilkesini gerçekleştirmeye yönelik bu kurala birtakım istisnalar getirilmiştir. YAŞ’ın terfi ile kadrosuzluk nedeniyle emekliye ayırma işlemleri (md. 125/2), HSK'nın meslekten çıkarma cezası hariç diğer kararları (md. 159/10) yargı denetimi dışında tutulmuştur. ${ }^{16}$ Öte yandan silahlı kuvvetler personeline uygulanan uyarma kınama ve hizmete kısmi süreli devam disiplin cezaları (md. 129/3, 6413 sayılı Kanun md. 43/1) ve spor federasyonlarının spor faaliyetlerinin yönetimine ve disiplinine ilişkin kararları ile bu kararlara karşı başvuru üzerine tahkim kurulu tarafından verilen kararlar (md. 59/3) da yargı denetimi dışındadır. ${ }^{17}$ Yargı yolu kapalı olan bu işlemler idarenin tek yanlı ve icrai işlemleridir. Dolayısıyla bu işlemler, ilgilisinin rızası gerekmeksizin hukuki sonuçlar doğu-

15 Ayrıntılı bilgi için bkz. KARAHANOĞULLARI, Onur, “İdarenin Yargısal Denetimine Yönelik Anayasa Değişiklikleri ve Takdir Yetkisinin Yargısal Denetimi", Mülkiye Dergisi, Cilt 35, Sayı 270, 2011, s. 43-64.

16 Yasama kısıntısı olarak nitelendirilen bu haller ve yargı kısıntıları (hükümet tasarrufları), Kaya tarafından idarenin takdir yetkisinin mutlak olduğu haller olarak ifade edilmiştir. KAYA, Cemil, İdarenin Takdir Yetkisi ve Yargısal Denetimi, On İki Levha Yayınları, İstanbul, 2011, s. 73 vd. Takdir yetkisi sınırsız bir yetki olmadığından mutlaklığından bahsetmek yerinde olmayacaktır. İdarenin takdir yetkisi hukuk kurallarının çizdiği çerçeve içerisinde kullanılmalıdır; kamu düzeni, kamu yararı ve kamu hizmeti gerekleriyle sınırlıdır. Aynı yönde Danıştay 5. Dairesi'nin 25.01.1995 tarihli ve E.1994/6864, K.1995/428 sayılı kararı, (Kazanc1). 
rurlar. Kişiler hakkında iradeleri dışında sonuç doğuran bu işlemlerin yargı denetimi dışında tutulması, hukuk devleti ilkesiyle bağdaşmamaktadir.

114. maddenin "yargı yolunun kapatılamayacă̆ına" ilişkin hükmü karşısında, 125. maddenin "yargı yolunun açık olduğuna" ilişkin hükmü daha az korumacı gözükmekle birlikte, idarenin işlemlerine karşı yargı yolunun kapatılması her halükârda Anayasaya aykırılık oluşturacaktır. 125. madde, 2. maddede yer alan, Türkiye Cumhuriyeti'nin "insan haklarına saygılı bir hukuk devleti olma" niteliğiyle birlikte yorumlandığında, idarenin yargısal denetimine ilişkin düzenleme "yargı yolunun açık olduğu ve kapatılamayacă̆ı" sseklinde anlaşılmaktadır.

Söz konusu Anayasa hükümleri, yarg1 yetkisinin yasama organı tarafından kısıtlanmasını düzenlemektedir. Bu nedenle "yasama kısıntısı" olarak adlandırılmaktadır. ${ }^{18}$ Yarg1 organının yetkisi sadece yasama organı tarafından değil, bazen de yargı organının bizzat kendisi tarafından kısıtlanmaktadır. Bunlara "yargı kısıntısı" adı verilmektedir. Yargı kısıntısı, önceden herhangi bir düzenlemeye bağlanmayan konularda yasama organı ile çatışmamak ve diplomatik sahalarda yasama organını zor durumda bırakmamak amacıyla yargı organının denetimden kaçınmasını ifade etmektedir. ${ }^{19}$ Yargı kısıntısının bir diğer adı hükümet tasarrufudur. Hukuk devleti ilkesinin özellikli bir unsuru olan idarenin yargısal denetiminin uygulama alanı, yasama ve yargı kısıntıları sebebiyle daralmaktadir. $^{20}$

\section{B. İPTAL DAVASI}

\section{Tanımı}

2577 sayılı İdari Yargılama Usulü Kanunu md. 2'ye göre; iptal davaları, idari işlemler hakkında yetki, şekil, sebep, konu ve maksat unsurlarından en az birinin hukuka aykırı olduğundan dolayı iptal edilmeleri için, menfaatleri ihlal edilen kişiler tarafından açılabilen davalardır. Ülkemizde, ilk kez 1925 tarihli Şuray-ı Devlet Kanunu'nda açıça yer bu-

\footnotetext{
18 AKYILMAZ/SEZGINNER/KAYA, İdare, s. 112 vd.

19 AKYILMAZ/SEZGİNER/KAYA, Yargı, s. 53 vd; ÇAĞLAYAN, İdare, s. 313 vd.

20 AKYILMAZ/SEZGINNER/KAYA, İdare, s. 112 vd; AKYILMAZ/SEZGİNER/KAYA, Yarg1, s. 53 vd.
} 
lan ve kararı veren makam dişında başka bir makamın onayına muhtaç olmadığı belirtilen iptal davası, 1961 Anayasası'nın 114. maddesiyle asıl anlamını kazanmıştır. ${ }^{21}$ Cumhuriyet'in ilanından sonra yapılan hukuki düzenlemelerde, idarenin yapmış olduğu işlemlerin denetiminin sadece bağımsız yargı organı tarafından yapılacağıyla başlayan hukuki güvence sağlamaya yönelik gelişmeler ${ }^{22}$, idarenin hiçbir işlemine karşı yargı yolunun kapatılamayacağı yönündeki bu hükümle devam etmiştir.

İptal davasının konusu, idarenin yaptığı idari işlemlerdir. Dava bakımından önem arz eden ve açıkça belirlenmesi gereken husus, işlemin kimliğidir. ${ }^{23}$ Davaya konu olabilmesi için işlemin idarece yapılması, kesin ve yürütülebilir, icrai ve tek yanlı olması gerekir. İşlemin sahibi olan davalı idare, işlem kadar önem arz etmemektedir. Bu nedenledir ki, dava dilekçesinde davalı idarenin hiç gösterilmemiş olması, hatalı gösterilmiş olması, eksik gösterilmesi veya uyuşmazlıkla hiç ilgisi bulunmayan idarenin/idarelerin gösterilmiş olması durumlarında yargı yeri davada doğru hasmı bulur, kimi zaman hasım çıkarma kararı verir ve böylece yargılamaya kaldığı yerden devam eder. Dilekçenin reddi sebebi sayılmaz (İYUK md. 15/1, c).

İptal davası, idari makamların ilgililer üzerinde hukuki sonuç doğuran tek yanlı irade açıklamalarının hukuka uygunluk denetimlerinin yapıldığı davadır. Hukuk devleti ilkesi gereği idarenin hukuka uygun hareket ettiği varsayılır. İdarenin yaptığı idari işlemler, idari yargı yerlerince hukuka aykırı oldukları tespit edilene kadar hukuka uygunluk karinesinden yararlanır. İptal davası, devletin, işlemlerini yaparken hukuka uygun hareket etmesi için etkili ve zorlayıcı bir güç oluşturmaktadır. Hukuk devleti ilkesinin güvencesi olduğundan, iptal davasını eşsiz

21 SEZGINNER, Murat, İptal Davasının Uygulama Alanı Bakımından Ayrılabilir İşlem Kuramı, Yetkin Yayınları, Ankara, 2000, s. 24 vd; İptal davasının tarihsel gelişim sürecine ilişkin ayrıntılı bilgi için bkz. SEZGİNER, s. 21 vd; KARAHANOĞULLARI, Onur, Türkiye'de İdari Yargı Tarihi, Turhan Kitabevi, Ankara, 2005, s. 37 vd.

22 Yargı kararlarını yürütmenin onayına tabi olmasını ifade eden tutuk adalet anlayışı, bu gelişme ile teoride aşılmıştır. Bkz. SEZGİNER, s. 21 vd; KARAHANOĞULLARI, İdari Yarg1 Tarihi, s. 37 vd.

23 İdari işlemin kimliğine ilişkin bilgi için bkz. ERKUT, Celal, İptal Davasının Konusunu Oluşturma Bakımından İdari İşlemin Kimliği, Danıştay Başkanlığı Yayını, Ankara, 1990. 
bir dava olarak nitelendirmek yanlış olmayacaktır. ${ }^{24}$ İdarenin hukuka aykırı işlemlerini ortadan kaldırılmasını sağlayacak başka bir dava söz konusu değildir.

İptal davası "actio popularis" nitelikli bir dava değildir. Herkesin bu davayı açma ehliyeti bulunmamaktadır. İYUK md. 2 gereği, iptal davalarına özgü olarak menfaat ihlali özel ehliyet şartı olarak belirlenmiştir.

\section{Hukuk Devleti İlkesi Bakımından Önemi}

İptal davası, idarenin yargısal denetimini sağlayan bir mekanizmadır. Hukuk devleti, temel ifadesiyle hukukla bağlı olan devlet demek olduğundan, ilke hukuka uygunluğu sağlayan iptal davası ile sıkı bir ilişki içerisindedir. İdare tarafından yapılan hukuka aykırı işlemlerin hukuk âleminden kaldırılması ve hukuk devleti ilkesine uygunluğu sağlamak iptal davasiyla mümkündür.

İptal davası, işlemi yapan idareyi ya da işlemin muhatabını değil, işlemin kendisini esas almakta ve işlem hakkında hüküm verilmektedir. Davada yargılanan, işlemi yapan idare değil, işlemin kendisidir. Bu nedenle işlemlerin denetlenmesinin önüne engeller koymamak, işlemi idari yargı önüne getiren kişiler bakımından menfaat kavramını esnek yorumlamak gerekir. ${ }^{25}$ Olması gereken, hukuk devletinde idarenin işlemlerinin yargısal denetimine sınır getirilmemesidir. İptal davası açma hakkının sınırlandırılması; hakkın kötüye kullanılarak idarenin sürekli ve herkes tarafından dava tehdidiyle karşı karşıya kalmaması ve faaliyetlerinin engellenmemesi gerekçesiyle tercih edilmektedir. ${ }^{26}$

Fransız hukukunda, iptal davası için "idare hukukunun en temel yapıtı" ya da "en iyi hukuk eseri" gibi ifadeler kullanılmıştır. Aktaran SEZGİNER, s. 20-21.

Danıştay'ın aksi yönde görüşleri bulunmaktadır: "Ancak, menfaat ilişkisinin olması gerekenden daha geniş kapsamlı olarak ele alınması, iptal davalarının objektifliğini zedeleyeceği gibi idarenin hukuka uygunluğun sağlamada en etkili yollardan biri olan bu davanın amacı ile de bağdaşmaz." Danıştay IDGK'nın 21.01.1988 tarih ve E.1987/47, K.1998/3 sayılı kararı, (Kazancı). Ancak belirtmek gerekir ki, Danıştay'ın yorumu yerinde değildir. Aksine menfaat ilişkisini geniş yorumlamak, hukuk devleti ilkesine hizmet edecektir.

26 GÖZÜBÜYÜK, Şeref, Yönetsel Yarg1, Turhan Kitapevi, Ankara, 2010, s. 167 vd; ŞENOL, s. $142 \mathrm{vd}$. 
İptal davası açabilecek kişileri belirlemede kullanılan menfaat ihlali, hukuk devleti ilkesini gerçekleştirme noktasında önem taşıyan bir kavramdır. ${ }^{27}$ İptal davasının uygulama alanın genişletebilecek daha esnek bir menfaat yorumu sayesinde, hukuk devleti ilkesi daha güvenceli hale gelecektir.

\section{III. İPTAL DAVASINDA SÜBJEKTIF EHLIYYTT KOŞULU: MENFAAT İHLALİ}

İptal davası açılabilmesi bakımından aranan ehliyet şartı iki aşamalıdır: Objektif ve sübjektif ehliyet. Objektif ehliyet ${ }^{28}$, idare hukukuna özgü olmayan, davaya taraf olabilme ve dava açabilme ehliyetini ifade ederken ${ }^{29}$, sübjektif ehliyet bir menfaatin ihlal edilmiş olmasını ifade eder. Menfaat ihlali, iptal davasının idari yargıya özgü sübjektif ehliyet ${ }^{30}$ şartıdır.

27 “Ayrıca, iptal davaları ile idari işlemlerin hukuka uygun olup olmadığının saptanmasına, hukukun üstünlüğünün sağlanmasına, böylece de idarenin hukuka bağlılığının belirlenmesine, sonuçta hukuk devleti ilkesinin gerçekleştirilebilmesine olanak sağlandığından bu davalarda menfaat ilişkisinin bu amaç doğrultusunda yorumlanması gerekmektedir." Danıştay IDDK'nın 06.10.2005 tarih ve E.2004/3, K.2005/2371 sayılı kararı, (Kazanc1).

28 İdari yargı alanında davaya taraf olma ve dava açabilme ehliyetleri konusunda IYYUK md. 31'de HMK'ya atıf yapılmıştır. HMK'da ehliyete ilişkin genel düzenlemeler şu şekildedir: *Taraf Ehliyeti, Madde 50: (1) Medenî haklardan yararlanma ehliyetine sahip olan, davada taraf ehliyetine de sahiptir. *Dava Ehliyeti, Madde 51: (1) Dava ehliyeti, medenî hakları kullanma ehliyetine göre belirlenir.

29 ŞENOL, s. 141; GÖÇGÜN, Faruk, İptal Davasında Sübjektif Ehliyet Koşulu Olarak Kişisel Menfaat Unsuru, Gazi Üniversitesi Sosyal Bilimler Enstitüsü, Yüksek Lisans Tezi, 2016, s. 29 vd.

30 Karahanoğulları, sübjektif ehliyet kavramını değil "ilgi bağı" kavramını tercih etmektedir. Yazar bu tercihin nedenini şu şekilde açılamaktadır: "Dava konusu ile davacının ilişkisini kurma ihtiyacının ifadesi olan menfaat-hak ihlali koşulunu ehliyet başlı̆ğ altında değerlendirebilmek mümkün değildir. Medeni yargılama hukukunda benzer koşul için "taraf sıfatı (husumet)" terimi önerilmektedir. "Sıfat, dava konusu sübjektif hak ile taraflar arasındaki ilişkidir. Taraf ehliyeti, dava ehliyeti ve davayı takip yetkisi, davanın taraflarının kişilikleriyle ilgili olduğu halde, taraf sıfatı dava konusu sübjektif hakka ilişkindir." İdari yargılama usulündeki "subjektif ehliyetle kastedilen aslında bu taraf sıfatıdır; fark -ya da tartışma- kaynağının subjektif hak olmamasıdır. Uygulamada ve öğretide, bu koşulun subjektif ehliyet kavramı içinde değerlendirilmesi, İYUK'ta, dava konusu işlemle yeterli ilgisi bulunmayan kişilerin davalarını reddedebilmek için dayanacak hükmün bulunmamasından kaynaklanmaktadır. Uygulamada, dava konusu işlemle yeterli ilgileri 
Objektif ehliyetin ifade ettiği davaya taraf olabilme ve dava açabilme ehliyeti, medeni hukukta yer alan hak ehliyeti ve fiil ehliyetinin yansımalarıdır. ${ }^{31}$ Ancak bu ehliyet, idari yargıda dava açabilmek için yeterli değildir. İdari yargıda bu genel ehliyet şartının yanında, iptal davası bakımından menfaat ihlali, tam yargı davası bakımından ise kişisel hak ihlali özel ehliyet şartı olarak aranmaktadır. İptal davası bakımından esasa değil, şekle ilişkin bir şart olan menfaat ihlalinin varlığ1, İYUK md. 14 gereği, mahkeme tarafından ilk inceleme aşamasında araştırılmaktadır. Menfaat ihlalinin bulunmaması halinde, IYYUK md. 15 gereği davanın reddine hükmedilmektedir.

İptal davası bakımından söz konusu olan menfaat kavramını tanımlayabilmek için, tam yargı davalarında aranan hak kavramıyla farklılığı ortaya konmalıdır. Menfaat, "hukuken korunan menfaat" olarak nitelendirebileceğimiz hak kavramını da kapsayan daha geniş bir kavramdir.

\section{A. KAVRAMSAL ÇERÇEVE}

\section{Menfaat Kavramı}

Menfaat, davacı ile iptali istenen işlem arasındaki alakadır. İdare tarafından yapılan bir işlemin hukuka aykırı olduğunu düşünen herkes, işlemin iptali için dava açamaz. Dava açabilmek için işlem ile kişi arasında menfaatin, yani ciddi ve makul bir alakanın olması aranır. ${ }^{32}$ İdari

kurulamayan kişilerin davaları 15. maddede bulunan "ehliyet" koşuluna dayanılarak reddedilmektedir. /Dava konusu işlemle davacı arasında yeterli ilgi bulunması koşulunu ifade etmek üzere, yargılama hukukunda locus standi terimi kullanılmaktadır. Bu terimin İngilizce karşılığı standing to sue dur. Fransızca da ise qualite ile anlatılmaktadır. Terimlerin hiçbiri ehliyet (yetenek) anlamı taşınmamaktadır. Davaya ehil olmak başka bir şey, ehil olduğu dava hakkını somut olayda kullanabilmek için uyuşmazlık konusu ile yeterli bir ilgiye sahip olmak başka bir şeydir. $\mathrm{Bu}$ nedenle, incelememizde subjektif ehliyet terimi yerine ilgi bağı terimini kullanacağız." KARAHANOĞULLARI, Onur, "Birel İşleme Karşı Açılan İptal Davalarında İlgi Bağ1 Sorunu", AÜSBF Dergisi, Cilt 62, Say1 3, s. 201-233, http://80.251.40.59/politics.ankara.edu.tr/karahan/makale/ilgibagi.htm, (09.01.2021).

31 ŞENOL, s. 141; İdare hukukunda geçerli husumet kavramıla bağlantılı anlatım için bkz. GÖÇGÜN, s. 30 vd.

32 ONAR, Sıddık Sami, İdare Hukukunun Umumi Esasları (Cilt III), İsmail Akgün Matbaası, 3. Bası, İstanbul, 1966, s. 1781; “Taraf ilişkisinin kurulması için gerekli olan kişisel, meşru ve güncel bir menfaat alakasının varlığı, davanın niteliğine ve özelliğine göre idari yarg1 yerlerince belirlenmekte, davacının idari işlemle ciddi ve 
işlemin yargı mercii önüne götürülebilmesi için işlem ve davacı arasında var olması gereken yeterli alaka, menfaat kavramıyla karşılanmaktadır. ${ }^{33}$

Fransız hukukunda menfaat ihlali, "l'intérêt donnant qualité à agir (dava açmaya yeterli ilgi)" kavramiyla ifade edilmektedir. ${ }^{34}$ Burada kullanılan "agir" kavramı dava açmak, harekete geçmek, tepki vermek gibi anlamlara gelmektedir. Menfaat ihlali ile anlatılmak istenen alakanın boyutu, aslında bu kavram ile daha doğru ifade bulmaktadır. Dava konusu işlemin davacının buna tepki vermesine neden olacak düzeyde davacı üzerinde etki yaratması söz konusudur. Alman hukukunda ise, "sübjektif kamusal hak" kavramı, iptal davası bakımından dava ehliyetini ifade etmektedir. Y1lmaz, sübjektif kamusal hak kavramı ile "korunmaya değer bireysel menfaatin" ifade edildiğini belirtmektedir. ${ }^{35}$ Bireye, devlet ve kamu gücü kullanan makamlara karşı bir işlem yapılmasını, bir duruma göz yumulmasını ya da bir durumdan uzak durulmasını talep edebilme yetkisi veren ve kamu hukukundan kaynaklanan bir haktır. ${ }^{36}$

İYUK md. 2'de iptal davasının sübjektif (öznel) ehliyet koşulu "menfaat ihlali" olarak yer almışken; 4001 sayılı Kanunla ${ }^{37}$ bu koşul; çevre, tarihi ve kültürel değerlerin korunması ve imar uygulamaları gibi kamu yararını yakından ilgilendiren hususlar dışında "kişisel hak ihlali" olarak değiştirilmiştir. Bu değişiklikle iptal davasının objektif niteliği, sübjektifleştirilmeye çalışılmıştır. ${ }^{38}$ İptal davasının niteliğiyle uyuşmayan bu durum karşısında, ilgili madde, Anayasanın 2. ve 36. maddelerine aykırılık gerekçesiyle Anayasa Mahkemesi önüne taşınmıştır. Mahkeme,

makul, maddi ve manevi bir ilişkisinin bulunduğunun anlaşılması, dava açma ehliyeti için yeterli sayılmaktadır." Danıştay IDDK'nın 06.10.2005 tarih ve E.2004/3, K.2005/2371 sayılı kararı, (Kazancı).

ÖZAY, İl Han, Günışığında Yönetim II Yargısal Korunma, On iki Levha Kitabevi, İstanbul, 2010, s. 152.

CHAPUS, René, Droit du Contentieux Administratif, Paris, 2002, s. 425 vd.

YILMAZ, Dilşat, “Alman İdari Yargılama Hukukunda İptal Davası”, Gazi Üniversitesi Hukuk Fakültesi Dergisi, Cilt XIII, Sayı 1-2, 2009, s. 308.

YILMAZ, s. 308.

2577 sayılı İYUK'da değişiklik yapan 4001 sayılı Kanun, 18.06.1994 tarih ve 21964 sayılı Resmî Gazetede yayımlanmış ve yürürlüğe girmiştir.

Ayrıntılı bilgi için bkz. YÜCESOY, Ayşe Aslı, İdari Yargılama Hukukunda İptal Davalarında Menfaat, Seçkin Yayınları, Ankara, 2016, s. 111 vd. 
21.09.1995 tarihli ve E.1995/27, K.1995/47 sayılı kararıla ${ }^{39}$, idari işlemlere karşı iptal davası açılabilmesi için aranan, işlemle davacının kişisel hakkının ihlal edilmiş olması şartının, hak arama özgürlügünü kısıtlayan ve pek çok işleme karşı dava yolunu kapatan, bu sebeplerle de hukuk devleti ilkesiyle bağdaşmayan bir şart olması gerekçesiyle Anayasa md. 2 ve md. 36'ya aykırı bulunduğundan iptaline hükmetmiştir. ${ }^{40}$

İptal davası bakımından menfaat ihlali yerine hak ihlali şartının aranması hukuk devleti ilkesiyle bağdaşmayan bir durum ortaya çıkarmıştır. İptal davası hukuk devleti ilkesini gerçekleştirmenin en etkin aracıdır ve bu aracın kullanımı amacıyla bağdaşmayacak biçimde sınırlandırılmamalıdır. Anayasa Mahkemesi, ilgili kararıyla bu hukuka aykırılıktan dönülmesini sağlamıştır. İptal davasında yargılanmakta olan, bir idari işlem olduğundan, hukuka aykırılığını ortaya koymak ve işlemi iptal etmek gerekir. Bu taleple mahkemeye başvurulması hakkını, sadece işlemle kişisel hakkı ihlal edilmiş olan kişilere tanımak, davanın amacına hizmet etmesini engelleyeceğinden, dava konusu işlemle arasında yeterli bir alaka bulunanların dava açabilmesi kabul edilmiştir.

Menfaat kavramını "kamu yararı" kavramı ile birlikte değerlendirmek gerekir. Kamu yarar1 ${ }^{41}$, toplumun tümüne yönelik bir menfaati ifade etmektedir. İdare tüm işlemlerini kamu yararı amacını gerçekleştirmek için yaptığına göre, bu amaca hizmet etmeyen işlemler bakımından aslında toplumsal menfaati ihlal edilen herkesin dava açabilmesi gerekir. Kamu yararı kavramı göz önünde bulundurulduğunda, menfaat ihlali hukuk devleti ilkesiyle daha uyumlu biçimde yorumlanacaktır.

Menfaat kavramı, yalnızca maddi bir menfaati değil, aynı zamanda manevi menfaati de ifade etmektedir. Dava konusu işlem, her zaman maddi bir menfaati ihlal etmeyebilir. Bazen ihlal edilen, manevi bir menfaattir. Nazım Hikmet'in vatandaşlıktan çıkarılmasına dair kararının nüfus kütüğüne tescili işleminin iptali istemiyle açılan davada, Danıştay İDK, idari işlemle davacı arasında ciddi, makul, maddi ve manevi bir

39 İlgili karar, 10.4.1996 tarih ve 22607 sayılı Resmî Gazetede yayımlanmıştır.

40 Anayasa Mahkemesi kararına ilişkin bir değerlendirme için bkz. KOÇAK, Mustafa, "Hukuk Devleti Kavramı Açısından İptal Davasında Menfaat İhlali ve Hak İhlali Koşulu", Hukuk Araştırmaları Dergisi, Cilt 10, Sayı 1-3, 1996, s. 125 vd. 
ilişkisi bulunmasını, dava açma ehliyeti bakımından yeterli saymıştır. ${ }^{42}$ Danıştay'ın daha eski tarihli kararlarında da konu aynı şekilde ele alınmıştır ${ }^{43}$ İptal davası açılabilmesi için ihlal edilmiş bir kişisel hakkın bulunması gerekli olmayıp, olayda bir alakanın bulunması yeterlidir.

İptal davalarında menfaat ihlali şartının aranması, aslında dava ehliyetini sınırlandıran bir düzenlemedir. İptal davasının hukuk devleti ilkesine sıkı sıkıya bağlı olması, bu davayı herkesin açabilmesini, yani actio popularis nitelikte olmasını gerektirir. Ancak daha önce belirttiğimiz üzere, idarenin sürekli ve herkes tarafından dava tehdidiyle karşı karşıya kalmaması ve faaliyetlerinin engellenmemesi için dava ehliyeti sınırlandırılmıştır; iptal davası actio popularis nitelikte değildir. ${ }^{44} \mathrm{Bu}$ durumda, menfaat kavraminın kapsaminı, sinırlandırılmasının sınırını belirleyecek olanın kim olduğu sorusu gündeme gelmektedir. Bu belirleme, bizim idare hukuku sistemimizde yargı yerlerince yapılmaktadır.

42 “Taraf ilişkisinin kurulması için gerekli olan kişisel, meşru ve güncel bir menfaat alakasının varlığı, davanın niteliğine ve özelliğine göre idari yargı yerlerince belirlenmekte, davacının idari işlemle ciddi ve makul, maddi ve manevi bir ilişkisinin bulunduğunun anlaşılması, dava açma ehliyeti için yeterli sayılmaktadır." Danıştay İDDK'nın 06.10.2005 tarih ve E.2004/3, K.2005/2371 sayılı kararı, (Sinerji); Çelikkol, Conseil d'Etat'nın kilise çanlarının çalınmaması yolundaki bir belediye kararına karşı papazlar tarafından açılan davayı kabul etmesini Fransız yargı kararlarından örnek göstermiştir. Bkz. ÇELIKKKOL, Hüseyin, "İdari Yargıda Ehliyet ve Husumet", Adalet Dergisi, Yıl 76, Sayı 3, Mayıs-Haziran 1985, s. 763.

43 “...iptal davalarında ortada ihlal edilmiş bir hakkın mevcudiyeti davanın cereyanı için lazımeden olmayıp, hadisede sadece bir alakanın bulunması, alakadara dava açma salahiyetini vermeye kâfidir. Davacının ise muamele vergisi mükelleflerinden olması itibari ile dava arzuhallerinde yazılı tamimle alakası zahirdir." Danıştay Dava Daireleri Umumi Heyeti'nin 03.07.1936 tarih ve E.1936/9, K.1936/157 sayılı kararı için bkz. Kararlar Mecmuası, Sayı 8, s. 43-44.

44 "Biz de hukuka bağlı bir idarenin varlığında herkesin menfaati olduğuna katılmakla birlikte iptal davası açabilmek için bu genel menfaatin dışında davacı ile dava konusu işlem arasında bir ilgiyi belli bir çerçeveyi anlatan yani isteyen herkese dava açma hakkı vermeyen bir menfaatin varlığı gerektiği düşüncesindeyiz. Ancak bu koşulu bir idari işlemden dolayı yalnızca hakkı ya da çıkarı ihlal edilenlerin veya zarar görenlerin dava açabileceği biçiminde dar yorumlamak hukuk devleti ilkesinin gerçekleşmesi olanağını zayıflatacak, her işleme karşı her bireyin dava açmasını sağlayacak biçimde geniş yorumlamak da mahkemeleri gayriciddi davalarla uğraşmak zorunda birakacaktır." YÜCESOY, s. 87 vd. 
Özyörük, belirlemenin kanun koyucu tarafından yapılmasının hukuka saygılı idare ilkesi gereği doğru olmayacağını belirtmiştir..$^{45}$

Görüldüğü üzere, menfaat kavramı, hak ihlali kadar dar yorumlanmayan, üst sınırının belirlenmesi ise yargı yerlerine bırakılmış olan bir dava ehliyeti şartıdır.

\section{Hak Kavramı}

Hak, hukuk kuralları tarafından tanınmış menfaattir. Ancak vurgulamak gerekir ki; bu tanımlama menfaat kavramının ilave bir değer kazanmasını ifade ederken, hak kavramı bakımından bir değer kaybetmesini ifade etmemektedir. Şenol, "hukuk kurallar tarafindan, kişilere, diğer kişilerin davranışları ya da malları üzerinde tanınmış olan yetkiler" olarak ifade etmiştir. ${ }^{46}$ Hak kavramı daha çok özel hukuk alanında kullanılan bir kavramdır. İdari yargı alanında ise, özel hukuk alanındaki tazminat davalarıyla benzerlik gösteren tam yargı davaları bakımından bu kavramdan bahsederiz. Özel hukuk bakımından hak kavramı "hukuken korunan çıkar, bir kişiye izafe edilebilen davranış" olarak ifade edilebilir. ${ }^{47}$ İdare hukuku kapsamında genel anlamı ise, hukuken korunan çıkardır.

Atay, hak kavramını şu şekilde tanımlamıştır48: "Hak, genel kuralların somut bir olay ve işlemle örtüştürülüp, ilgilisi açısından diğerlerine karşı ileri sürülebilen, talep edilen ve korunmasına ilişkin birtakım yöntem ve mekanizmaların olduğu bir hukuki yetki ve talep imkânıdır. Bu anlamda hak kavramı kişisel bir durumla bağlantılıdır ve bir sübjektifliği içerir." Tanımdan anlaşıl-

45 “Bu sinırlama, kanunlarla yapılmaz. Zira o zaman, hukuka saygılı idare ilkesinde, bu sayg1 yükümünün karşılığı olan 'sübjektif hakkı' tespit etmek gerekir. Halbuki... idarenin hukuka saygısı, belli sübjektif hakların alanını aşan, bu alanın dışına taşan bir yükümdür. O halde, idarenin hukuktan ayrıldığı her yerde, bir sübjektif hak söz konusu olmaksızın, ihlal edilmiş en yakın menfaatin veya menfaatlerin sahibini, hukuka aykırılığın konusu ve tesirlerinin yaygınlığı itibariyle zaman zaman ve hadisesine göre tespit gerekir ki, bunu ancak bir mahkeme (=Danıştay) yapabilir." ÖZYÖRÜK, s. 206.

46 ŞENOL, s. 143.

47 Hakkı tanımlayan teoriler ve hak kavramı konusunda ayrıntılı bilgi için bkz. EREN, Fikret, Borçlar Hukuku Genel Hükümler, Yetkin Yayınları, Ankara, 2015, s. 46 vd; OĞUZMAN, Kemal/BARLAS, Nami, Medeni Hukuk (Giriş-KaynaklarTemel Kavramlar), Vedat Kitapçılık, İstanbul, 2013, s. 137 vd.

48 ATAY, Ender Ethem, Hukuk Başlang1cı, Gazi Kitabevi, 8. Baskı, Ankara, 2020, s. 365. 
dığı üzere, hak kavramı hukuk tarafından korunan ve kişilerle sıkı ilişkili menfaattir. Bu tanımlama çerçevesinde, hak kavramı, menfaat kavramina göre daha sinırlı bir anlama sahiptir. Hak söz konusu olduğunda, hukuken korunan bir menfaat söz konusudur. Somutlaştırılmış bir örnekle ifade etmek gerekirse, örneğin bir belediyenin yetki sınırları içerisindeki bir bina hakkında aldığı yıkım kararı, bina malikinin hukuken korunan bir menfaatine ilişkindir: Mülkiyet hakkı. Ancak belediyenin belde sınırları içinde yeşil alanları yok edip yerine bir alışveriş merkezi yapmaya ilişkin aldığı karar karşısında, işlemle aynı belde sakini arasında hukuken korunan kişisel bir menfaatten bahsedilemese de makul bir alakadan, salt bir menfaatten bahsetmek mümkündür. Söz konusu iki durumda da ilgili kişinin iptal davası açması mümkündür. Ancak iptal davası bakımından ehliyet şartı olarak hak ihlali aranıyor olsaydı, sadece ilk örnek için dava açılabilirdi. Menfaatin zarar gördüğü ikinci durumda dava açlamıyor oluşu, iptal davasının hukuk devleti ilkesiyle olan ilişkisine aykırılık oluştururdu.

Hak ihlali şartı, yargı yerlerinde dava açabilmek için aranan şarttır. Kişisel bir hakkınız ihlal edildiyse, hakkınızı aramak için yargı yerlerine başvurursunuz ve mahkeme buna kanaat getirdiğinde davacı bakımından ehliyet şartının gerçekleştiğine hükmeder.

\section{3. İki Kavramın Karşılaştırılması}

Menfaat kavramı, hak kavramından daha geniş bir alakayı ifade etmektedir. ${ }^{49}$ Bir işlem kişinin doğrudan hukuken korunan bir kişisel hakkını ihlal etmese bile, menfaatini ihlal etmiş olabilir. Ancak her menfaat ihlali, hak ihlali anlamina gelmemektedir.

Menfaat, hukuki koruma bakımından hak kadar kuvvetli olma$\mathrm{y}^{5} \mathrm{p}^{50}$, ciddi ve makul bir alakadan ibarettir. Söz konusu menfaat aslında bir hak ihlalini de karşılayabilir; ancak burada önemli olan, iptal davası

49 Konuya ilişkin detaylı bilgi için bkz. AKYILMAZ, Bahtiyar/SEZGİNER, Murat/KAYA, Cemil, Türk İdari Yargılama Hukuku, 4. Baskı, Savaş Yayınevi, Ankara, Eylül 2020, s. 241 vd; GÖKALP ALICA, Süheyla Suzan, “Çevrenin Korunmasına İlişkin İptal Davalarında Kişisel Menfaat Kavramı", Türkiye Barolar Birliği Dergisi, 2018 (139), s. 167 vd. 
açabilmek için menfaat ihlalinin yeterli olmasıdır. Hak kadar güvenceli bir çıkarın ihlal edilmesi gerekmez.

Menfaat kavramının, hak kavramından farkı, her zaman kişiselleştirilememesindedir. Hak kavramı, her daim kişiyle sıkı sıkıya bir bağ içerisindedir. Ancak menfaat kavramı kişiyle sıkı bir bağı gerektirmez. İşlem ile kişi arasında makul ve ciddi bir alaka yeterli olur. Dava konusu işlem, herhangi bir kimseyi doğrudan ya da dolaylı olarak olumsuz yönde etkilerse menfaat ihlalinden söz edilebilir. ${ }^{51}$

Hukuk devleti ilkesi gereği, işlemin hukuka aykırı olması tüm hukuk düzeniyle, dolayısıyla devletin her bir bireyiyle alakalıdır. Ancak pratik sebepler iptal davasının herkes tarafından açılmasını mümkün kılmamaktadır. İdarenin yargısal denetimi mekanizmasını harekete geçirme imkânı herkese tanınırsa, ilgili ilgisiz herkes dava açıp, idarenin işleyişini zorlaştırabilir. ${ }^{52}$ Íptal davası ehliyetini kişiselleştirilmiş hak kavramından daha geniş yorumlama ihtiyacı, bu nedenle doğmuştur.

\section{B. MENFAAT KAVRAMININ ÖZELLIKLERI}

İptal davasının açılabilmesi için IYYUK md. 2' de öngörülmüş bulunan menfaat ihlali şartının gerçekleşmesi için, menfaatin birtakım nitelikleri haiz olması gerekir. Menfaatin sahip olması gereken nitelikler, yarg1 içtihatları ile belirlenmiştir ${ }^{53}$ : İhlal edilmiş olan menfaatin meşru, güncel ve kişisel olması gerekir. ${ }^{54}$

51 AKYILMAZ/SEZGİNER/KAYA, Yarg1, s. 86; ÇAĞLAYAN, Ramazan, İdari Yarg1lama Hukuku, Seçkin Yayınları, 11. Baskı, 2019, s. 453 vd.

52 GÖZÜBÜYÜK, s. 165.

53 “...2577 sayılı Yasa'nın 2. maddesinin 1/a fıkrasında; iptal davalarının "idarî işlemler hakkında yetki, şekil, sebep, konu ve maksat yönlerinden biri ile hukuka aykırı olduklarından dolayı iptalleri için menfaatleri ihlâl edilenler tarafından açılan" davalar olarak tanımlandığı, yargı kararlarında "menfaat" kavramının davacı ile iptalini istediği idarî işlem arasındaki bağı, ilgiyi ifade ettiği belirtilmekte ve idarî işlem ile dava açan kişi arasında meşru, güncel ve ciddî bir ilişki söz konusu ise, davada menfaat bağının bulunduğunun kabul edildiği, bunun dışında ayrıca sübjektif bir hakkın ihlâl edilmesi koşulunun aranmadığı, dolayısıyla iptal davasının gerek anılan maddede, gerekse içtihat ve doktrinde belirlenen hukukî nitelikleri göz önüne alındığında, idare hukuku alanında tek taraflı irade açıklamasıyla kesin ve yürütülmesi zorunlu nitelikte tesis edilen idarî işlemlerin, bu idarî işlemle meşru, kişisel ve güncel bir menfaat ilgisi kurabilenler tarafından iptal davasına konu edilebile- 


\section{Güncel Olma}

Menfaatin güncel olması, dava açıldığı anda mevcut olması anlamına gelir. Dava konusu idari işlem ile davacı arasında alakanın dava açıldığı anda mevcut olması gerekir. Alaka mevcut değilse menfaatin güncel olmadığından bahisle ehliyet unsurundan dolayı dava reddedilir. Ortada bir menfaatin bulunmaması halinde menfaat bakımından diğer koşulların incelenmesi gerekli değildir. Sonuçta mevcut olmayan bir menfaatin meşru ya da kişisel olup olmadığı önem arz etmeyecektir.

Gözübüyük, kural olarak "davanın açıldığı anda ya da dava karara bağlanırken" menfaatin bulunmasını güncellik olarak ifade etmiştir. ${ }^{55}$ Ancak İYUK md. 15'te açıkça düzenlendiği üzere, dava açıldı̆̆ı anda mevcut bulunmayan bir menfaat söz konusu ise dava ehliyet yönünden reddedilecektir. Dolayısıyla kullanılan " ya da" ifadesi yerinde değildir.

Danıştay önüne gelen bir davada, ilk derece mahkemesi, bakılan davayı kayyım sıfatıyla açan davacının kayyımlık sıfatının yargı kararı ile kaldırıldığının anlaşıldığı, dava konusu işlemle ilgili menfaatin davanın sonuna kadar devam etmesi gerektiğinin idare hukuku ilkelerinden olduğu, yargı kararı sonucu dava konusu işlemle ilgisi kalmayan davacının açmış olduğu davanın esasının incelenemeyeceği gerekçesiyle ehliyet yönünden reddine karar verilmiştir. Danıştay, ilk derece mahkemesinin bu kararını hukuka aykırı bulmuştur. İdari işlemin tesisi edildiği ve davanın açıldığı tarih itibariyle meşru, güncel ve kişisel bir ehliyetin mevcut olduğu, sonradan meydana gelmiş olan değişikliklere dayanılarak ehliyet yönünden reddini hukuka uygun görmemiştir. ${ }^{56} 57$

ceğinin kabulünün zorunlu bulunduğu..." Danıştay İDDK'nın 18.06.2009 tarih ve E.2009/1356, K.2009/1679 sayılı kararı, (Kazanc1).

54 Fransa'da genel kabul menfaatin kişisel (l'exigence que l'intérêt soit personnel), meşru (l'exigence que l'intérêt soit légitime) ve güncel (l'exigence que l'intérêt soit pertinent) olmasıdır. Ancak bunun yanında ikinci bir görüşe göre; menfaatin doğrudan (l'appréciation du caractère suffisamment direct de la lésion) ve kesin (l'appréciation du caractère suffisamment certain de la lésion) nitelikte olması da aranir. Bkz. CHAPUS, s. 435 vd.

55 GÖZÜBÜYÜK, s. 185.

56 “...davayı açtığı tarihte kayyım olduğu, ancak dava derdest iken kayyımlık kararının 5.6.1996 tarihli yargı kararı ile kaldırıldı̆̆ı tartışmasız olup, işlemin tesis edildiği ve dava konusu edildiği tarih itibariyle, meşru, güncel, kişisel ehliyeti bulundu- 
İleride doğması muhtemel bir menfaat bulunduğundan bahisle iptal davası açılması mümkün değildir; çünkü ortada güncel bir menfaat bulunmamaktadır. ${ }^{58}$ Ancak, doktrinde yakın gelecekte doğması muhtemel zararlar açısından, zararlı sonuçlar doğmadan evvel, iptal davası açılabileceği savunulmaktadır. ${ }^{59}$ İdari yargılama usulümüze göre, menfaat ihlalinin gerçekleşmemesi halinin davanın reddi sonucuna yol açması karşısında, bu görüşü savunmak mümkün değildir (İYUK md. $15 / 1, b)$.

\section{Meşru Olma}

Menfaatin, iptal davası bakımından aranan nitelikte olabilmesi için öncelikle meşru olması gerekir. Meşru menfaat, hukukun koruduğu menfaat demektir. Kanunlarla korunan ve kamu vicdanının kabul ettiği menfaat meşrudur..$^{60}$ Öte yandan meşru menfaat, hukuka ve ahlaka aykırı olmayan menfaati ifade eder. ${ }^{61}$

Hukuka aykırı bir durumun mevcudiyeti halinde, meşru bir menfaatten söz etmek mümkün olmayacaktır. Danıştay 6. Dairesi, belediye meclis üyesinin menfaatinin meşru ve kişisel olmadığı gerekçesiyle ehliyet yönünden iptal talebini reddetmiştir: “...yukarıda belirtildiği gibi taşınmazlar kamuya tahsisli olmadığından, imar planlarının ve değiş̧ikliklerinin

ğu açık olan davacının durumunda sonradan meydana gelen değişiklikler dikkate alınmak suretiyle davanın esasının çözümlenmeyerek ehliyet yönünden reddedilmesinde hukuka uyarlık görülmemiştir." Danıştay 10. Dairesi'nin 10.04.2000 tarih ve E.1997/6341, K.2000/1372 sayılı kararı, (Kazanc1).

57 Danıştay 6. Dairesi'nin 29.03.1967 tarihli ve E.1963/1569, K.1967/826 sayılı kararında, belirttiğimiz kararın aksi yönde bir hükümle karşılaşmaktayız. İlgili kararda, dava devam ederken davacının dava konusu işlem ile olan ilgisinin ortadan kalkması nedeniyle ehliyet yönünden davanın reddedildiği ifade edilmiştir. Ancak sonraki kararlarında Danıştay'ın dava açıldığı anda mevcut menfaat durumunu dikkate aldığını görmekteyiz. Bkz. GÖZÜBÜYÜK, s. 186-187; Konuya ilişkin tartışmalar için bkz. GÖÇGÜN, s. 55 vd; ÇELIKKKOL, s. 764-765. GÖZÜBÜYÜK, s. 185; ÇAĞLAYAN, Yargı, s. 457; ŞENOL, s. 147.

Görüşler için bkz. YILDIRIM, Turan, İdari Yargı, Beta Yayınları, İstanbul, 2010, s. 389; KAYA, Cemil, “Íptal Davalarında (Kişisel) Menfaat İhlalinin Genişlemesi: İktisadi Rekabet", İstanbul Üniversitesi Hukuk Fakültesi Dergisi, Cilt LXVI, Sayı 2, 2008, s. 273

60 ÇELİKKOL, s. 764.

61 Chapus, menfaatin hukuka ve ahlaka aykırı olmaması gerektiğini belirtmiştir: “...pour la sauvegarde d'une situation irrégulière ou immorale.”. CHAPUS, s. 435. 
onayı ile yasal olarak görevli belediye üyesi olan davactnın, planlarını mecliste görüşülmesi sırasında toplantılara katılması ve gerekirse karşı oyunu bu toplantılarda belirtmesi gerekirken bu yolla belde halkının hakkını koruma görevini yerine getirmeyen davacmın, kararın oluşmasından sonra dava açmakta meşru ve kişisel bir menfaati de bulunmadı̆̆ 1 sonucuna varılmıştır. "62

İşlem nedeniyle menfaati ihlal edilen kişiler tarafından iptal davası açabilecek olup menfaatin kişisel ve güncel olması yanında meşru olması da aranır. Danıştay, menfaatin meşru olmasının, hukuken ileri sürülebilir olmasını gerektirdiğini belirtmiştir ${ }^{63}$. Karardan anlaşılacağı üzere; hukuk devleti ilkesini gerçekleştirmeye hizmet eden iptal davası bakımından aranan menfaatin meşru olması, davanın mahiyeti bakımından anlaşılır bir şarttır.

Danıştay kararlarında "kiracı olma" bazen meşru menfaat olarak değerlendirilirken bazen de meşru menfaat olarak değerlendirilmemiştir. ${ }^{64} 2006$ tarihli bir kararda65; taşınmaz maliki tarafından uygulanmak istenen ve koruma kurulunca da uygun bulunan restorasyon projesinin taşınmazın kiracısının projenin iptalini isteme konusunda "meşru menfaati bulunmadığından" idare mahkemesince verilen kararda isabet görülmediğini karara bağlamıştır. 2007 tarihli bir kararında ${ }^{66}$ ise aynı daire, kiracı olmayı meşru menfaat olarak değerlendirmiştir: “...tahliyesine ilişkin işleme karşı bu taşınmazda kiracı olarak faaliyet gösteren davacı tarafından açılan davada... anılan yapıların yıkılması durumunda zararın ortaya çıkacă̆ı açık olup, yıkım ve tahliye işlemlerinin dayană̆ı olan 'Adnan Menderes Sahil Yolu Projesi' davacının menfaatini etkileyeceğinden, bu davayı açmakta

62 Danıştay 6. Dairesi'nin 28.01.1993 tarih ve E.1992/4605, K.1993/237 say1lı kararı, (Corpus).

63 Danıştay 10. Dairesi'nin 13.11.2002 tarih ve E.2002/1407, K.2002/4320 sayılı kararı, (Kazanc1).

64 Alman Federal Mahkemesi, yol planlamasına ilişkin işlemlere karşı kiracının dava açamayacağını karara bağlamıştır. Aksi yönde kararları da bulunmakla birlikte Mahkemenin genel yaklaşımı bu yöndedir. Aktaran YILMAZ, s. 308.

65 Danıştay 6. Dairesi'nin 19.07.2006 tarih ve E.2005/7113, K.2006/3928 sayılı kararı için bkz. ŞENOL, s. 145; Aynı yönde Danıştay 6. Dairesi'nin 05.03.1975 tarih ve E.1973/3117, K.1975/1330 sayılı kararı için bkz. Danıştay Altıncı Daire Kararları (1965-1977), Danıştay Tasnif ve Yayın Bürosu Yayınları, 1979, s. 614.

66 Danıştay 6. Dairesi'nin 11.05.2007 tarih ve E.2006/1414, K.2007/2757 sayılı kararı için bkz. ŞENOL, s. 145. 
meşru ve güncel menfaati bulunduğundan..." Bu konuda doğru olan, taşınmaza ilişkin işlemlerin kiracıları da ilgilendirdiği, arada işlemin iptalini talep etmeye yetecek bir ilişkinin olduğu yönündeki değerlendirmedir.

Sınai Mülkiyet Hizmetleri Dan. ve Org. Ltd. Şirketi'nin Türk Standartları Enstitüsü Yönetim Kurulu'nun Ürün Belgelendirme Yönergesinin 10/2. maddesinin iptali için açtığ 1 davada ${ }^{67}$, Danıştay kiracının meşru bir menfaati bulunmadığına hükmetmiştir. Karara göre, dava konusu edilen yönerge hükmü, TSE dışında başka bir kişinin hukuki durumuna doğrudan etki etmemektedir. Bu nedenle, hukuka aykırı bir eylem ile marka hakkına saldırıda bulunulduğunu ileri süren davalı idarenin, adli yargıda açacağı tazminat davalarında isteyeceği miktarın belirlenmesine yönelik ve iç işleyişine ilişkin yönergenin iptalinin istenilmesinde, davac1 şirketin hukuken korunması gereken, meşru bir menfaati bulunmamaktadır.

\section{Kişisel Olma}

Menfaatin kişisel olması, dava konusu işlemin davacıya doğrudan ya da dolaylı bir etkisinin bulunması demektir. ${ }^{68}$ Danıştay'a göre, menfaatin kişiselliğinden söz edebilmek için iptali istenilen işlemin doğrudan doğruya davacı hakkında yapılmış olması gerekmez. ${ }^{69}$

Kişisellik özelliği, işlemin davacıyı etkiler nitelikte olmasını ifade ettiğinden, menfaat ihlalinin "kapsamı içtihatlar çerçevesinde belirlenen özelliği" olarak nitelendirilebilir. Meşru olma ve güncel olma, kişisel olma karşısında daha objektif olarak belirlenebilir anlamlara sahiptir. Ancak kişisel olma özelliği, tamamen yargı yerlerinin somut olayın koşullarına göre değerlendirip ortaya koyduğu sübjektif bir özelliktir. Danıştay kararlarında vatandaş, vergi yükümlüsü, belde sakinleri, dernek-

67 Danıştay 10. Dairesi'nin 28.01.2011 tarih ve E.2010/7285, K.2011/215 sayılı kararı, (Kazanc1).

68 AKYÜREK, Akman, “Danıştay Kararlarında İptal Davalarının Menfaat İhlali Koşulunun Kişisellik Unsuru”, Danıştay Dergisi, Sayı 80-81, s. 31 vd; ONAR, s. 1872; AKYILMAZ/SEZGİNER/KAYA, Yarg1, s. 245 vd; ÇAĞLAYAN, Yargı, s. 458.

69 Danıştay IDDK'nın 21.03.2007 tarih ve E.2005/1582, K.2007/378 sayılı kararı, (Kazanc1). 
ler, barolar gibi menfaat süjelerinin/gruplarının dava konusu işlemle kişisel menfaatlerinin olup olmadığı tartışılmaktadır. ${ }^{70}$

Menfaat kavramından anlaşılması gereken, menfaatin meşru ve güncel olan kişisel bir menfaat olduğudur. ${ }^{71} \mathrm{Bu}$ haklı değerlendirmede vurgulandığı üzere, menfaatin temel özelliği kişisel olması olup, meşru ve güncel olması kişisellik özelliğini sağlamış olan menfaat bakımından aranacak şarttır. Menfaatin bu sübjektif özelliği belirlendikten sonra, objektif özellikleri değerlendirilmelidir.

Danıştay, kişisel olma özelliğini şu şekilde ifade etmiştir ${ }^{72}$ : İster gerçek ve ister tüzel kişi olsun Danıştay'da dava açabilmek için, dava açanın, "dolaylı veya dolaysız" bir kişisel menfaatinin ihlal edilmiş olması gerekir. Danıştay'ın bir başka kararında ${ }^{73}$ da kişisel menfaatin varlığından söz edebilmek için işlemin doğrudan doğruya davacı hakkında yapılmış olması gerekmediğini vurgulamıştır. Kararlardan anlaşıldığı üzere, kişisellik vurgusu işlemin "doğrudan doğruya davacı hakkında" olması ifadesiyle yapilmamaktadır.

Danıştay İDDK, Yükseköğretim Kurulu kararına karşı bir üniversite tarafından yapılan itirazın reddine ilişkin bir başka YÖK kararının iptali talebiyle açılan davada ilk derece mahkemesinin süre yönünden reddettiği davayı, ehliyet yönünden sakat olduğu gerekçesiyle bozan Danıştay ilgili dairesi kararını hukuka uygun bulmuştur. ${ }^{74}$ Kararda, ida-

70 Örnek kararlar için bkz. Bölüm II/C, s. 21 vd.

71 GÖÇGÜN, s. 57.

72 Danıştay 5. Dairesi'nin 06.06.1970 tarih ve E.1969/4390, K.1970/3355 sayılı kararı, Danıştay Dergisi, Sayı 2, s. 175; GÖZÜBÜYÜK, s. 173.

73 “...menfaatin kişisel menfaat sayılabilmesi iptali istenilen işlemin doğrudan doğruya davacı hakkında alınmasını gerektirmemektedir. Çevre, tarihi ve kültürel değerlerin korunması imar uygulamaları gibi kamu yararını ilgilendiren konularda dava açma ehliyetinin bu durum göz önünde bulundurularak geniş yorumlanmak suretiyle saptanacağı, Danıştay içtihatlarıyla kabul edilmiş bulunmaktadır." Danıştay IDDK'nın 21.03.2007 tarih ve E.2005/1582, K.2007/378 sayılı kararı, (Kazanc1).

74 "İdari faaliyetlerinin hukuka uygunluk denetimini etkili biçimde yapabilmeye olanak veren iptal davalarının, idari işlemle kişisel menfaat ilgisi kurulabilen kişiler tarafından açılması mümkündür. İdari işlemlerin muhatabı vatandaşlar veya başka bir idare olabileceği gibi idarenin ajanları da olabilir. Daire kararında da belirtildiği üzere; iptal davaları genellikle gerçek kişiler tarafından açılmakta ise de muhatabının bir başka kamu tüzel kişiliği olması halinde kamu kurumlarının birbirlerinin işlemlerine karşı dava açma ehliyetlerinin bulunduğunun kabulü gerekmektedir. 
ri faaliyetlerin hukuka uygunluk denetiminin etkili biçimde yapılabilmesine olanak veren iptal davalarının, idari işlemle kişisel menfaat alakası kurulabilen kişiler tarafından açılması gerektiği belirtilmiştir.

\section{YARGI KARARLARINDA YER ALAN MENFAAT SÜJELERİ VE GRUPLARI}

Danıştay kararları çerçevesinde birtakım menfaat süjelerini ve gruplarını bu başlık altında değerlendireceğiz. Bahsi geçecek birtakım süjeler veya gruplar, menfaat kavramının esnek yorumlanması sonucu, ilgili oldukları işleme karşı dava açabilmişlerdir.

Menfaat süjeleri ve grupları, menfaatin kişisellik özelliğine ilişkindir. Dava konusu işlemle davacı arasında kişisellik bağı tesis edilebilirse dava incelenir. Kişisellik bağı tesis edilemiyorsa, yani işlemle davacı arasında dolaylı ya da doğrudan bir etkileşim yoksa iptal talebi reddedilir. Aradaki alakanın geniş yorumlanması iptal davasının uygulama alanını genişleteceğinden hukuk devleti ilkesine hizmet edecektir. Öte yandan adil yargılanma hakkını ve hak arama özgürlüğünü destekleyici olarak menfaat kavramının geniş yorumlanması ve bu sayede idarenin denetlenmesi alanının genişlemesi ile hukuk devleti ilkesini gerçekleştirme bakımından fayda sağlanacaktır. Menfaat kavramının dar yorumlanması sonucu bireyler, adil yargılanma hakkı bağlamında mahkemeye

Ancak bazı idari işlemler, ayrı tüzel kişiliğe sahip kuruluşların birbirine eklenen ön işlemleri ya da başvurularıyla oluşabilmektedir. Böyle durumlarda, kamu kurumlarının birlikte oluşturdukları ya da kendi başvuru veya itirazları sonucu oluşan işlemlere karşı dava açma ehliyetlerinden söz edilemez. Tersi durum, işlemlerin oluşumunda izlenen yöntemsel akış sonucu oluşan tek yanlılığın, İşleme katkısı olan idari birimleri de kapsaması gerekliliği ve kaçınılmazlığıyla çelişir. Bu durum ise idari güven ve tutarlılık ilkesiyle bağdaşmayacağı gibi, tek yanlı irade açıklamasının ilgilisi olan kişiye tanınan dava hakkının, işlemi yapan birime de tanınması sonucunu doğurur. Dava konusu uyuşmazlıkta, disiplin soruşturması ve ön işlemlerin davacı üniversite tarafından yapıldığı, bu hazırlayıcı verilere dayanarak alınan dava konusu kararın, davacı kurumu da kapsadığı tartışmasızdır. Dolayısıyla davacı üniversitenin anılan işlemin iptali istemiyle dava açma ehliyeti bulunmamaktadır." Danıştay IDDK'nın 16.02.2006 tarih ve E.2005/3482, K.2006/29 sayılı kararı, (Kazanc1). 
erişim hakkının ihlal edildiği gerekçesiyle Anayasa Mahkemesi'ne bireysel başvuruda bulunmaktadır. ${ }^{75}$

İnceleyeceğimiz Danıştay kararlarına dayanarak, menfaat ilişkisinin gerektiği gibi esnek yorumlandığını söyleyebiliriz. Örneğin, ülkenin vatandaşı olmak, devletin gördügü ya da gördürdüğü kamu hizmetlerinden yararlanıyor olmak, vatandaşların yasama meclisindeki temsilcisi olmak, bir beldede ikamet etmek, belirli bir amaç doğrultusunda bir araya gelmiş kişilerden oluşan bir topluluk olmak, idarelerce yapılan işlemlerle ciddi ve makul bir alakanın tesisine imkân verebilmektedir. Bu gibi hususlar kişisel menfaat ihlalini belirlemede yararlanılan kriterlerdir. Yargı kararlarına konu olmuş farklı kriterler de mevcuttur. ${ }^{76}$

\section{Vatandaş Sıfatını Haiz Olanlar}

Vatandaş sıfatının kişilere dava açma hakkı verip vermeyeceği konusu, Danıştay kararlarında istikrar kazanmış bir uygulamaya sahip değildir. Doktrinde, Danıştay kararları doğrultusunda77, "vatandaşlık sıfatının kural olarak tek başına idari işlemlere karşı dava açma hakkı vermeyeceği" yönünde değerlendirmeler yapılmıştır. ${ }^{78}$ Birel işlemler dışında ${ }^{79}$, salt vatandaş olmak ya da kamu hizmetinden yararlanmak gibi ilişki biçimleri tek başına dava açma hakkı doğurmaz. Ancak aksi yönde ka-

AYM, Levent Tütüncü, B. No: 2015/3690, KT. 18.07.2018; AYM, Kemal Çakır ve diğerleri [GK], B. No: 2016/13846, KT. 05.03.2020; AYM, Arif Ekim ve diğerleri, B. No: 2016/9276, KT. 08.09.2020; AYM, Ragıp Cumhur Velibeyoğlu, B. No: 2017/34720, KT. 09.09.2020. Mahkemeye erişimin bir diğer görünümü olan karar hakkının ihlali gerekçesiyle yapılan başvuru örnekleri için bkz. AYM, Bayram Ali Devecioğlu, B. No: 2017/39387, KT. 15.09.2020; AYM, Şenol Arslan, B. No: 2017/40261, KT. 15.09.2020; AYM, Yılmaz Aksu, B. No: 2018/18444, KT. 03.12.2020; AYM, Abdullatif Ucaman ve diğerleri, B. No: 2018/1833, KT. 02.12.2020.

77 “...her ne kadar iptal davalarında dava ehliyetinin bir unsuru olarak menfaat ilişkisi... daha geniş tutulmakta ise de, bu temayülün, tüm vatandaşlara, her idari işlem aleyhine, salt vatandaş olma sıfatıyla dava açma hakkı sağlayacak şekilde genişletilmesine de olanak bulunmamaktadır." Danıştay DDK'nın 25.01.1974 tarih ve E.1972/586, K.1974/80 sayılı kararı, ŞENOL, s. 153, dipnot 56. ÇAĞLAYAN, Yarg1, s. 464 vd.

79 Birel işlemler, belli bir kişiye yönelik, somut ve özel bir düzenleme içeren işlemler olduğundan, burada salt bu işlemin ilgilisi olmak dava açma bakımından yeterlidir. 
rarlar bulunduğundan, kural olarak vatandaşlık sıfatının dava açma ehliyeti sağlamayacağını söylemek yerinde değildir.

Danıştay 10. Dairesi, Yusuf Bozkurt Özal'ın naaşının Süleymaniye Camii haziresine defnine izin verilmesiyle ilgili Bakanlar Kurulu Karar1nın iptali talebiyle açılan davada, davacı vatandaşın bu işlemle kişisel bir menfaatinin ihlal edilmediği, işlemle davacı arasında ciddi ve makul bir menfaat bağının bulunmadığı, davacının avukat ve vatandaş olmasının kanunun aradığı manada bir menfaat ilişkisinin kurulmasında yeterli olmadığı gerekçesiyle davayı ehliyet yönünden reddetmiştir. Danıştay IDDK ise, davacının vatandaşlık sıfatı ile dava konusu işlem arasında yeterli bir ilginin bulunduğu ve davacı vatandaşın taşınmaz kültür ve tabiat varlıklarının korunması açısından menfaat sahibi olduğundan bahisle ilk derece mahkemesinin ehliyet yönünden red hükmünü bozmuştur. ${ }^{80}$

Danıştay IDDK'nın kararına yazılan karşı oyda vatandaşlık sıfatı, kişisel menfaat dışında değerlendirilmiştir. ${ }^{81}$ Karşı oyda, öncelikle IYYUK'a göre, idari işlemler hakkında menfaati ihlal edilenler iptal davası açabileceği ve menfaat ihlalinin objektif bir dava olan iptal davalarının esasının görülebilmesi için gerekli olduğu ifade edilmiştir. İhlal edilen menfaatin, kural olarak kişisel olması gerekliliği de vurgulanmıştır. Vatandaşlara, her idari işlem aleyhine dava açma hakkı yasal düzenlemeyle tanınmadığı ve özellikle Hükümetin ekonomik kararlarına karşı, salt vatandaş olma sıfatının iptal davası açabilme hakkı tanımadığı ifade edilmiştir. Karşı oya göre, dava konusu uyuşmazlıkta davacı vatandaş-

80 “...dava konusu Bakanlar Kurulu Kararı ile defin yapılacak olan yerdeki Süleymaniye Camii ve çevresinin, İstanbul Kültür ve Tabiat Varlıkları Koruma Kurulunun 12.7.1995 günlü, 6848 sayılı kararıyla "kentsel ve tarihi SİT, kentsel ve arkeolojik SİT alanı" olarak kabul ve ilan edilmiş olduğu iddiasıyla, söz konusu Bakanlar Kurulu Kararının iptali istemiyle, taşınmaz kültür ve tabiat varlıklarının korunması açısından her vatandaşın dava açmada menfaatinin bulunduğunun kabulü gerekeceğinden, davacının vatandaş olarak bir kişinin belediye mezarlığ defnini öngören Bakanlar Kurulu Kararının iptalini istemekte menfaati bulunduğu açık olup; davanın ehliyet yönünden reddi yolunda verilen kararda hukuka uygunluk bulunmamaktadır." Danıştay IDDK'nın 19.10.2001 tarih ve E.2001/415, K.2001/737 sayılı kararı, (Kazanc1).

81 Danıştay IDDK'nın 03.05.2007 tarih ve E.2004/2303, K.2007/842 sayılı kararı, (Kazanc1). 
lık sıfatının ötesinde kişisel menfaatini açıkça ortaya koyamamıştır. Salt vatandaş olma sıfatı iptal istemi açısından yeterli görülmemiştir. Yüksek mahkeme ise, ilgili kararda, oyçokluğu ile ehliyet yönünden vatandaşlık sıfatını kabul etmiştir.

Özellikle üstün bir kamu yararından bahsedebileceğimiz tarihi ve kültürel değerlerin korunması ${ }^{82}$, çevrenin korunmas $^{83}$ gibi hallerde dava açma ehliyeti geniş yorumlanmakta ve vatandaşlık sıfatı kabul edilmektedir. ${ }^{84}$ Kanaatimizce bu değerlendirme, hukuk devleti ilkesi bakımından yerindedir. Kamuyu ilgilendiren konularda, vatandaş sıfatını haiz olanların dava açma ehliyetinin geniş yorumlanması gerekir. İptal davasının sübjektif ehliyet şartı olan menfaat ihlali, bu tür konularda vatandaşlar bakımından gerçekleşmiştir.

Vatandaş sıfatını haiz olmanın dava ehliyeti sağlamayacağı yönündeki mahkeme kararının, mahkemeye erişim hakkını ihlal ettiği iddiasıyla yapılan bireysel başvuruda Anayasa Mahkemesi, Anayasa md. 36'da güvence altına alınan adil yargılanma hakkı kapsamındaki mahkemeye erişim hakkının ihlal edildiğine hükmetmiştir. ${ }^{85}$ Oyçokluğuyla alınan karara yazılan karşı oyda, sırf bir bölge sakini olmak, çevreye duyarlı vatandaş bulunmak vb. soyut nedenlerle, çevreye zarar verdiği

82 Danıştay IDDK'nın 19.10.2001 tarih ve E.2001/415, K.2001/737 sayılı kararı, (Kazan$\mathrm{Cl}$ ).

83 Danıştay 10. Dairesi'nin 24.06.1986 tarih ve E.1985/2739, K.1986/1451 sayılı kararı için bkz. ÇAĞLAYAN, Yarg1, s. 464; Danıştay 10. Dairesi'nin 28.04.1992 tarih ve E.1990/2278, K.1992/1672 sayılı kararı, (Kazanc1).

84 "Çevre, tarihi ve kültürel değerlerin korunması, imar uygulamaları gibi kamu yararını yakından ilgilendiren konularda vatandaş, belde veya semt sakini sıfatıyla dava açılabileceği Danıştay İçtihatlarıyla kabul edilmiştir." Danıştay IDGK'nın 11.11.2004 tarih ve E.2004/741, K.2004/1854 sayılı kararı, (Kazanc1).

85 “42. Bireysel başvuruya konu olayda başvuruculara ait taşınmazların bulunduğu bölgeye çok yakın alanda yapılması planlanan RES üretim tesisi hakkında verilen ÇED gerekli değildir kararının uyuşmazlık konusu edildiği bir idari dava söz konusudur. Söz konusu idari işlemin iptali istemiyle açılan davada başvurucuların RES projesi kapsamına giren alanda taşınmaz sahibi olmadıkları, sadece vatandaş veya birey olmanın dava açma ehliyeti sağlamayacağı ve işlem nedeniyle menfaat ihlali bulunmadığı gerekçesiyle uyuşmazlığın esasının incelenmemesi nedeniyle başvurucuların mahkemeye erişim haklarına yönelik bir müdahalenin bulunduğu görülmektedir." AYM, Kemal Çakır ve diğerleri [GK], B. No: 2016/13846, KT. 05.03.2020, § 42 . 
öne sürülen yatırımların yapıldığı alanın dışında kalan kişilerce dava açılmasının menfaat ihlali kapsamı dişında kalacağı, Anayasa'nın “çevreyi geliştirmek, çevre sağhı̆̆ın korumak ve çevre kirlenmesini önlemek Devletin ve vatandaşların ödevidir" hükmünü (md. 56) öngörmesine karşın, bu hakkın maksadınca uygun biçimde yorumlanması gerektiği, davaya konu (Proje-1) sahasında taşınmazları bulunmayan başvurucular yönünden yargı yerlerince varılan sonucun adil yargılanma hakkı kapsamında mahkemeye erişim hakkının ihlâline yol açmadığı kanaatine varıldığ1 ifade edilmiştir. Kanaatimizce başvuruyu inceleyen bölümün vermiş olduğu ihlal kararı yerindedir. Çünkü başvurucuların proje kapsaminda olmamakla birlikte, projeden etkilenme potansiyelleri bulunduğu açıtır. İdari yargı yerince yapılan yargılamada dava açmaları imkânsız hâle getirilerek başvurucuların mahkemeye erişim hakkına yapılan müdahale, Anayasa Mahkemesi'nin belirttiği gibi, orantısızdır.

\section{Vergi Yükümlüsü Olanlar}

Danıştay, vergi yükümlüsü olmayı iptal davası açabilmek için yeterli bir alaka olarak görmediği bir kararında ${ }^{86}$, davacının vergi ödüyor olmasının her konuda kendisine sınırsız dava açma hakkı vermediğini ifade etmiştir. Davacı tarafından iptali istenen genelgeyle davacı arasında meşru, kişisel ve güncel bir menfaat bağı bulunmadığından davanın ehliyet yönünden reddine hükmedilmiştir.

Danıştay'ın aksi yönde bir kararında ${ }^{87}$; katma değer vergisinin mükellefi konumundaki her bireyin nihai tüketici olması dolayısıyla vergi oranları ile ilgili olarak toplumun tümünü dolayısıyla da kendi menfaatini zedeleyen, kamu yararına ve hukuk devleti ilkesine aykırı olan düzenleyici işlemlere karşı dava açma hakkı bulunduğundan bahsedilmiştir. Nihayetinde, davalı idarenin, davacıların menfaatleri bulunmadığ1 yönündeki defi yerinde görülmeyerek işin esas incelenmesine geçilmiştir.

\footnotetext{
86 Danıştay 10. Dairesi'nin E.1998/5840, K.1998/5848 sayılı kararı, ÇAĞLAYAN, Yargı, s. 461.

87 Danıştay 7. Dairesi'nin 11.03.2003 tarih ve E.2001/4997, K.2003/555 sayılı kararı, (Kazanc1).
} 
Danıştay, vergi yükümlüsünün iptal davası bakımından ehliyet sahibi olup olmadığı, yani menfaatinin ihlal edilip edilmediği konusunda istikrarlı bir içtihada sahip değildir. Somut olaylar doğrultusunda değerlendirme yapılmaktadır. Kanaatimizce bu konuda bir içtihat oluşturmak zordur. Kamuyu ilgilendiren vergi oranlarının belirlenmesi, vergi yükümlülügünün kapsamının genişlemesi ya da daralması gibi somut olaylar karşısında vergi yükümlülerinin menfaatlerinin ihlal edildiği ileri sürülebilir. Alman hukukunda iptal davası bakımından dava ehliyetini ifade eden "sübjektif kamusal hak" kavramının korunmaya değer bireysel menfaati ifade ettiğinden yukarıda bahsetmiştik. Bu kavram tam da bu tür vergisel işlemler bakımından anlam kazanmaktadır. Ancak kamuyu ilgilendiren bir yönü olmayan, tamamen birel bir işlemi ifade eden somut olaylar karşısında dava ehliyeti şartını genişletici uygulamamak gerekir.

\section{3. İlgili Mahalli Birimde İkamet Edenler}

Danıştay kararlarında, mahalli birimde yaşayanların, mahalli idarenin işlemlerine karşı dava açma ehliyetine sahip olduklarına hükmedilmektedir. Bu yöndeki değerlendirmelerde, tıpkı vatandaşlık sıfatında olduğu gibi "kamu yararı kavramı" ön plana çıkarılmaktadır. Belirli bir mahalli birimde yaşayan insanlar, kamu yararı güdülerek yapılan işlemlerin hukuka aykırı olmaları halinde iptallerini talep edebileceklerdir.

Vatandaş, belde veya semt sakini sıfatlarıyla çevrenin korunması, kültürel ve tarihi değerlerin korunması, imar uygulamaları gibi "kamu yararını yakından ilgilendiren konularda" iptal davası açılabileceği Danıştay içtihatlarıyla kabul edilmiştir. ${ }^{88}$ Danıştay, Bakanlar Kurulu'nun kamu yararını yakından ilgilendiren konular kapsamında bulunan turizm merkezi ilanına ilişkin kararına karşı aynı kentte yaşayan, belde sakini davacı tarafından açılan davayı kabul etmiştir. ${ }^{89}$ Kamu yararını yakın-

88 Danıştay IDGK'nın 11.11.2004 tarih ve E.2004/741, K.2004/1854 sayılı kararı, (Kazanc1).

89 “...davaciyla kamu yararını yakından ilgilendiren dava konusu karar arasında meşru, kişisel ve güncel menfaat ilgisinin olduğu açıktır. Nitekim Danıştay Altıncı Dairesince de, davacının turizm merkezi ilanına ilişkin karara karşı dava açma ehliyeti kabul edilmiştir. Düzenleyici işlem niteliğindeki bu işleme karşı dava açma ehliyeti bulunan bir kişinin, uygulama işlemini dava edemeyeceği düşünülemeyeceğinden, Dairece inşaat ruhsatının turizm merkezi ilanı işleminden bağımsız bir 
dan ilgilendiren karar ile davacı arasında meşru, kişisel ve güncel bir menfaat mevcuttur.

Davacıların uyuşmazlık konusu çevre düzeni planı revizyonunun iptali istemiyle açtıkları davada, dava açmada öznel ehliyet şartı olan menfaat ihlalini belde sakini sıfatına değil mülkiyet iddiasına dayandırmaları nedeniyle, taşınmaz ile davacılar arasında mülkiyet bağı söz konusu olmadığından ve adli yargıda görülen ve henüz sonuçlanmayan mülkiyet çekişmesi dava açma hakkını sağlamayacağından, Danıştay 6. Dairesi'nce davacıların dava açma ehliyetinin bulunmadığı gerekçesiyle davanın ehliyet yönünden reddine hükmedilmiştir. Temyiz incelemesinde Danıştay İDGK, ilgili taşınmazları kapsayacak şekilde rekreasyon alanı belirlenmesine yönelik işlem ile davacılar arasında ciddi ve makul bir menfaat bağının bulunduğunun açık olduğu ve davacıların sübjektif ehliyetinin varlığı sebebine dayanarak davanın esasının incelenmesi gerektiğine hükmederek, ilgili daire kararını bozmuştur. ${ }^{90}$ İlk derece yargılamasında dayanılan "adli yargıda görülen ve henüz sonuçlanmayan mülkiyet çekişmesinin" dava açma hakkı sağlamayacağı yönündeki değerlendirme, olayın idare hukuku bakımından varlığını göz ardı etmektedir. Adli yargıda görülen mülkiyet hakkı çekişmesi idari yargı bakımından ehliyet şartını etkilemeyecektir. Çünkü idari yargıdaki iptal davasında önemli olan kamu yararını ilgilendiren bir konuda menfaatin ihlal edilmiş olmasıdır.

Köy halkından olma da Danıştay kararlarına konu olmuş bir menfaat ihlali sebebidir. Karara konu olayda ${ }^{91}$, köy halkının mera harman

işlem olarak kabul edilmek suretiyle davacının bu işleme karşı dava açma ehliyetinin bulunmadığı sonucuna varılmasında isabet görülmemektedir." Danıştay DDK'nın 25.01.1974 tarih ve E.1972/586, K.1974/80 sayılı kararı, ŞENOL, s. 153, dipnot 56.

90 Danıştay İDGK'nın 13.06.1997 tarih ve E.1997/195, K.1997/400 sayılı kararı, Kazancı İçtihat Bilgi Bankası; Aynı yönde Danıştay 6. Dairesi'nin 11.03.2003 tarih ve E.2001/4997, K.2003/555 sayılı kararı, (Sinerji).

91 “...tüm köyün ve köylünün yaşama düzenini ve gelişimini ilgilendiren köy merasının sadece bir kişinin kullanımına verilmesi işleminin köy sakini davacının menfaatini ihlal ettiği gözetilmeksizin zilyetlik ya da mülkiyet ilişkisinden söz edilerek verilen davanın ehliyet yönünden reddine ilişkin kararda isabet görülmemiştir." Danıştay IDGK'nın 06.12.1996 tarih ve E.1995/396, K.1996/598 sayılı kararı, (Kazan$\mathrm{Cl})$. 
yeri olarak kullanımına tahsis edilen taşınmazların meralık vasfının kaldırılarak, tapuda hazine adına arsa olarak tescili yapılmış ve üçüncü şahsa ihale suretiyle satılmıştır. Yaşam düzenlerini etkilediğinden tüm köy sakinlerini ilgilendiren köy merasının sadece bir kişinin kullanımına verilmesi işlemi köy sakini davacının menfaatini ihlal ettiği gözetilmeksizin açılan dava ehliyet yönünden reddedilmiştir. IDGK, ilgili kararı bozmuştur.

İlgili kararlardan, Danıştay'ın mahalli birimde yaşayanlar ya da belde sakinleri konusunda genel kanaatinin sübjektif dava ehliyetlerinin bulunduğu yönünde olduğu anlaşılmaktadır. Kanaatimizce menfaat kavramının, kamu yararı kavramı göz ardı edilmeyerek geniş yorumlanmast yerindedir.

Mahalli idare (il) sakini sıfatının dava ehliyeti sağlamayacağı yönündeki mahkeme kararının, mahkemeye erişim hakkını ihlal ettiği iddiasıyla yapılan bireysel başvuruda Anayasa Mahkemesi, ihlal bulunduğuna karar vermiştir.92 Başvurucuların ikamet ettiği ilde ÇED olumlu kararının iptali istemiyle açılan davada başvurucuların proje kapsamına giren alanda taşınmaz sahibi olmadıkları ve proje etki alanında bulunmamaları sebebiyle dava konusu işlemde menfaat ihlali bulunmadığı gerekçesiyle uyuşmazlığın esasının incelenmemesi nedeniyle başvurucuların mahkemeye erişim haklarına yönelik bir müdahalenin bulunduğu kararda ifade edilmiştir (§ 38). Karar incelendiğinde, bireylerin hukuki durumu üzerinde birtakım etki ve sonuçlar doğuran, bireylerin menfaatlerini etkilediği açık olan konularda menfaat kavraminı geniş yorumlamak gerektiğinin desteklendiği ve kamu yararı ile bireysel menfaatler arasında adil bir denge sağlanması gerektiği sonuçlarına varılmaktadır.

\section{Topluluklar (Dernekler-Sendikalar-Meslek Kuruluşları-Siyasi Partiler)}

Toplulukların iptal davası açmada ehliyet sahibi olmaları konusu çeşitli süreçlerden geçmiştir. Örneğin, dernekler önceleri sınırlı konularda menfaat sahibi sayılırken zamanla menfaat alanları genişlemiştir. 
Baroların menfaat süjesi olarak kabulü de zaman içerisinde, hukuk devleti ilkesi çerçevesinde genişlemiştir.

Dernekler, önceleri sadece doğrudan derneğe yönelik işlemler karşısında menfaat sahibi kabul edilirken; daha sonra, tüzüğünde açık bir düzenleme yer alıyorsa, derneklerin üyelerine yönelik işlemler karşısında da menfaat sahibi oldukları kabul edilmiştir. Danıştay bir kararında durumu şu şekilde açıklamıştır93: Dava konusu yönetim kurulu kararı, dernek üyelerinin demokratik, ekonomik, sosyal ve özlük haklarını korumak amacıyla kurulan derneğin faaliyet alanına giren, dernek üyelerinin personel hukukundan kaynaklanan ve dernek kişiliğinin hak ve çıkarlarını ilgilendiren konulardan olduğundan, derneğin karara karşı dava açmakta menfaati bulunmaktadır. Davacı derneğin sübjektif ehliyetinin varlığı kabul edilmek suretiyle davanın esasının incelenmesi gerekmektedir.

Danıştay, ilgili Derneğin tüzüğünde belirtilen amaçları arasında "hekimlerin haklarını korumak" ifadesi yer aldığından, derneğin dava ehliyetine sahip olduğuna hükmetmiştir. ${ }^{94}$ Başka bir kararda ${ }^{95}$, davacı derneğin tüzügünde ormanların yok edilmesini önleme amacı olmasına rağmen dava açma hakkından bahsedilmediğinden, derneğin menfaati olmadığına hükmedilmiştir. Karara göre, dernek tüzügünnde derneğin amaçlarının gerçekleştirilebilmesini teminen dava açma yolunun öngö-

93 “...kendi üyelerinin hak ve menfaatlerini korumak amaciyla kanunla kurulmuş meslek birliklerinin yanında, belli amaçlarla kurulmuş dernek, vakıf gibi özel hukuk tüzel kişiliğini haiz sivil toplum örgütlerinin de, kuruluş amaçlarıyla sınırlı olmak üzere dava açmaları mümkündür..." Danıştay İDGK'nın 26.05.2000 tarih ve E.1999/390, K.2000/761 sayılı kararı, (Kazanc1).

94 “Veteriner Hekimleri Derneği Tüzüğünün 2.maddesinde derneğin, veteriner hekimler arasında toplumsal dayanışmayı sağlamak amacıyla kurulduğu derneğin ve bu amacı gerçekleştirebilmek için veteriner hekimlik mesleğinin halk yararına en iyi şekilde düzenlenmesini ve gelişmesini sağlamaya çalışacağı, veteriner hekimliğin ve veteriner hekimlerin sorunlarını çözümlemeye çalışıp haklarını koruyacağı belirtildiğinden davacı derneğin, üyelerinin hukukunu korumak amacıyla dava açabileceği anlaşılmaktadır. Bu nedenle davalı idarenin, davacı derneğin dava ehliyeti bulunmadığı yolundaki iddiası yerinde görülmemiştir." Danıştay 5. Dairesi'nin 27.11.1996 tarih ve E.1996/2, K.1996/3674 sayılı kararı, (Kazanc1).

95 Danıştay 8. Dairesi'nin 07.12.1999 tarih ve E.1999/2477, K.1999/7077 sayılı kararı, (Kazanc1); Aynı yönde Danıştay 10. Dairesi'nin 27.09.2004 tarih ve E.2004/5645, K.2004/6431 sayılı kararı, (Kazanc1). 
rülmemiş olması, ormanların yok edilmesini önleme amacıyla derneğe sübjektif ehliyet tanımamaktadır. Ancak ormanların yok edilmesini önleme amacıyla dava açılabilmesi işin doğası gereği olması gereken bir durum olduğundan kararın yerinde olduğunu söylemek mümkün değildir. Kanaatimizce vatandaş sıfatını haiz olma da bu konuda yeterli alakayı kurmaktadır. Dernek tüzügünde yer alan amaca hizmet eden konularda dava açma ehliyetinin olduğu kabul edilmelidir.

Sendikaların, üyelerini ilgilendiren işlemler hakkında dava açma ehliyetleri bulunmaktadır. ${ }^{96} 4688$ sayılı Kamu Görevlileri Sendikaları ve Toplu Sözleşme Kanunu madde 19/2, f ve 6356 sayılı Sendikalar ve Toplu İş Sözleşmesi Kanunu madde 26/2'ye göre sendikalar üyelerini temsilen dava açabilir. Danıştay'a göre, çalışma hayatında iktisadi ve sosyal hak ve menfaatlerin geliştirilmesi ve korunması amacıyla kurulmuş olan sendikaların ilgili yasa hükümlerinde yer alan hususlara ilişkin davalarda sübjektif dava ehliyeti bulunmaktadır. Olayda, sendikanın iptalini istediği Yem Fabrikasını içeren satış işlemi gerçekleşmeden söz konusu fabrikaların çalışanlarına satılması konusunda önerilerde bulunulmuş, ancak öneriler ihaleden önce değerlendirilmemiştir. Davacı sendikanın üyelerini ilgilendiren bu işlemin iptali hususunda menfaat ihlali bulunduğundan davanın ehliyet yönünden reddedilmesinde Danıştay hukuki isabet görmemiştir. ${ }^{97}$ Sendikaların tüm üyelerini ilgilendirmeyen işlemlere karşı dava ehliyetine sahip olmadığına ilişkin de açık bir Danıştay kararı bulunmaktadır.98 Kararda, sendikanın kendi üyeleri arasındaki rekabete ilişkin konularda sübjektif dava ehliyetine sahip olmadığı belir-

96 Sendikaların sübjektif dava ehliyetine ilişkin detaylı bilgi için bkz. KAYA, Cemil, “Danıştay Kararları Işı̆̆ı̆ıda İptal Davaları Açısından Sendikaların Sübjektif Dava Ehliyeti", Prof. Dr. Ali Naim İnan'a Armağan, Ankara, 2009, s. 1215 vd.

97 Danıştay 10. Dairesi'nin 21.05.1996 tarih ve E.1995/4319, K.1996/2743 sayılı kararı, (Kazanci).

98 “...sendikalar, üyelerinin genel ekonomik yararlarını ve çalışma koşullarını ilgilendiren konularda dava açabilirler, kendi üyeleri arasındaki rekabet içerikli ekonomik konularda sendikanın dava açabileceği düşünülemez. Davacıya ait ekmek fırınına Konak Belediyesince verilen çalışma izni konusunda, Türkiye Ekmek Sanayi işverenler Sendikasının üyelerinin genel menfaatinin zedelendiğini ve bu nedenle de izin işlemine karşı iptal davası açma ehliyeti bulunduğunu kabul etmeye olanak yoktur." Danıştay 8. Dairesi'nin 09.03.1992 tarih ve E.1991/917, K.1992/438 sayılı kararı, (Sinerji); ÇAĞLAYAN, Yargı, s. 467. 
tilmiştir. Tüm üyelerini ilgilendiren konularda, kurulma amacı çalışma hayatında iktisadi ve sosyal hak ve menfaatlerin geliştirilmesi ve korunması olan sendikaların dava ehliyetinin bu amaçlar doğrultusunda oldukça esnek, geniş yorumlanması yerindedir.

Avukatlık Kanunu'nun 2. maddesi gereği avukatlığın amacı, hukuk kurallarının tam olarak uygulanmasını sağlamak olduğundan, genele yönelik işlemlere karşı dava açma bakımından baroların sübjektif ehliyetlerinin olduğunu yargı kararlarında savunulmaktadır. Bu savunma haklı ve yerindedir. Avukatlık Kanunu'nun 76. maddesinde Baroların tanımı yapılırken mesleğe ilişkin görevleri dışında hukukun üstünlüğü ile insan haklarını savunmak ve korumak görevlerine vurgu yapılmaktadır. Baro yönetim kurulunun görevlerini düzenleyen 95. maddede ise, hukukun üstünlügü ile insan haklarını savunmak, korumak ve bu kavramları işlevsel kılmak sayılmaktadır. İptal davası, sayılan bu görevleri yerine getirmenin en etkili yoludur. Bu nedenle hukukun üstünlüğü ve insan haklarının sağlanması ve korunması noktasında Baroların dava ehliyetinin varlığ 1 kabul edilmekle kalmamalı99, mümkün olduğunca geniş yorumlanmalıdır.

Meslek kuruluşlarının dava ehliyetleri bakımından Danıştay'ın istikrarlı bir içtihadından bahsedilemese de son dönemde özellikle Baroların açtıkları davalarda menfaat ihlali kavramının, olması gerektiği gibi, geniş yorumlandığını görüyoruz. Örneğin, Danıştay YÖK'ün katsayı kararına karşı İstanbul Barosu tarafından açılan davada, İstanbul Barosu'nun menfaatinin ihlal edildiğine hükmetmiştir. ${ }^{100}$ Karara göre, Avu-

\footnotetext{
99 YÜCESOY, s. 67.
}

100 Danıştay 8. Dairesi'nin 20.11.2009 tarih ve E.2009/6890 sayılı kararı, (Kazanc1). Danıştay 8. Dairesi, İstanbul Barosu'nun YÖK'ün katsayı işlemine yönelik bir başka kararına karşı açtı̆̆ı davada; “...̇̇ptal davalarındaki subjektif ehliyet koşulu, doğrudan doğruya hukuk devletinin yapılandırılmasına ve sürdürülmesine ilişkin bir husustur. Dolayısıyla kişisel menfaat ihlali kavramının, idari işlemlerin hukuka uygunluğunun iptal davası yoluyla denetlenmesini engellemeyecek bir biçimde anlaşılması gerekmektedir. Bireylerin ve sivil toplum kuruluşlarının menfaat ilgisini kurdukları idari tasarrufları, iptal davası yoluyla idari yargı önüne getirmelerinin, idarenin hukuka uygunluğunun yargısal denetiminin sağlanmasıyla "Hukuk Devleti"nin gerçekleştirilmesine hizmet edeceği; soruna bu açıdan bakıldığında, idari yargıya özgü bir dava türü olan "iptal davası"nı açan gerçek veya tüzel kişilerin, dava açmakla ulaşmak istediği amaç bakımından klasik anlamda "davacı"dan fark- 
katlık Kanunu'nun 76. maddesinde; baroların, hukukun üstünlüğünü savunmak ve korumakla görevli olduğu belirtildiğinden, sadece kendi meslek grubunu ilgilendiren iş ve işlemler açısından hukuki görev ve sorumlulukları bulunduğu savunulamaz. Davaya konu YÖK uygulamasının, hukuk düzeni üzerindeki etki ve sonuçları dikkate alındığında, baroların ilgili kanunlarında belirlenen görevleri kapsamında İYUK'un 2. maddesi kapsamında iptal davası açmak için aranan menfaat ihlali şartının varlığından söz edilebileceğinden, davalı YÖK Başkanlığı'nın davacı İstanbul Barosu Başkanlığı'nın dava açma ehliyeti bulunmadığı yolundaki itirazı yerinde görülmemiş ve işin esas incelemesine geçilmiştir. Davada verilen yürütmenin durdurulması kararına karşı IDDK'ya yapılan itirazda Kurulca, Baroların dava açma ehliyetine sahip olması tartışılmış ve menfaat kavramı Avukatlık Kanunu md. 2 gereğince geniş yorumlanmıştır. ${ }^{101}$

lı olduğu tartışmasızdır. Aksi yönde bir anlayış, iptal davasının önkoşullarından olan "menfaat ihlali"ni "hak ihlali"ne yaklaşan bir tarzda yorumlama sonucu yaratır ki, bu durumun ne idari yargının varlık nedeni ile ne de yasa koyucunun amacı ile bağdaşmayacağı açıktır..." şeklinde hüküm kurmuştur. Bkz. Danıştay 8. Dairesi'nin 27.01.2010 tarih ve E.2010/2 sayılı kararı, (Kazancı); Baroların iptal davası açma ehliyetinin kendisini ilgilendirmeyen işlemlere ilişkin olması halinde kabul edilmesi doktrinde eleştirilmektedir. Çağlayan, eğitim hizmetlerine ilişkin idari işlemle baroların kişisel menfaat ilişkisi bulunmadığından dava açamamaları gerektiğini savunmaktadır. Bkz. ÇAĞLAYAN, Yargı, s. 469-470.

101 “Davacı Baro olduğuna göre, kişisel menfaat ihlali kavramının Barolar yönünden değerlendirilmesine gelince; 1136 sayılı Avukatlık Kanunu'nun 76. maddesinde; baroların avukatlık mesleğine mensup olanların müşterek ihtiyaçlarını karşılamak, mesleki faaliyetlerini kolaylaştırmak, avukatlık mesleğinin genel menfaatlere uygun olarak gelişmesini sağlamak amacıyla kurulmuş meslek kuruluşları olduğu belirtilmiş iken 10.5.2001 günlü, 24398 sayılı Resmi Gazete'de yayımlanarak yürürlüğe giren 4667 sayılı Yasa ile 1136 sayılı Avukatlık Kanunu'nun 76. maddesinde değişiklik yapılarak; Barolar, avukatlık mesleğini geliştirmek, meslek mensuplarının biribirleri ve iş sahipleri ile olan ilişkilerinde dürüstlüğü ve güveni sağlamak, meslek düzenini, ahlakını, saygınlığını, hukukun üstünlüğünü, insan haklarını savunmak ve korumak, avukatların ortak ihtiyaçlarını karşılamak amacıyla tüm çalışmaları yürüten, tüzel kişiliği bulunan, çalışmalarını demokratik ilkelere göre sürdüren kamu kurumu niteliğinde meslek kuruluşu olarak tanımlanmış, aynı Yasanın Baro Yönetim Kurulu'nun görevlerinin düzenlendiği 95. maddesine yine 4667 sayılı Yasayla eklenen 21. bentte de, yönetim kurulunun, hukukun üstünlüğünü ve insan haklarını savunmak, korumak ve bu kavramlara işlerlik kazandırmakla görevli olduğu belirtilmiştir. 1136 sayılı Yasa'nın 76. ve 95/21. maddelerinde yapılan ve yukarıda açıklanan yasal değişiklikten sonra Baroların; mesleki bir örgüt olmanın öte- 
Buna karşın, İzmir Barosu'nun, Adli ve İdari Yargı hâkim ve Cumhuriyet savcıları ile diğer görevlilerine ödenecek yol tazminatının ödeme usul ve esaslarının yeniden düzenlenmesine ve ilgili yol tazminatına sınırlama getiren yasal düzenlemelerin açıklanmasına ilişkin genelgenin iptali talebi karşısında Danıştay, meşru ve kişisel bir menfaatinin ihlal edilmediğine hükmetmiştir. ${ }^{102} \mathrm{Bu}$ kararda hukuk kurallarının doğru uygulanması amacı çerçevesinde Baronun menfaatini göz önünde bulundurmamıştır.

Rize İdare Mahkemesi 20.09.2016 tarihli kararında ${ }^{103}$, Cerattepe Bakır Madeni, Kırma Eleme Tesisi ve Teleferik Hattı projesine yönelik ÇED olumlu raporuna karşı açılan davada, Türkiye Barolar Birliği'nin ve Artvin Barosu'nun menfaat ihlali bulunmadığına hükmetmiştir. Gerekçe olarak, kuruluş amacının esas aldığı faaliyet alanında üyelerinin ve temsil ettikleri kişilerin ortak hak ve çıarlarını korumak olduğu anlaşıldığı, ancak faaliyet alanları arasında çevre ve doğanın korunması, güzelleştirilmesi, daha sağlıklı ve yaşanabilir hale getirilmesinin bulunmadı ̆̆ı, çevrenin ve ekosistemin tahrip edilmesinin, biyolojik çeşitliliğin azalmasının, ekolojik dengenin bozulmasının baroların sadece tüzel kişilikleri açısından kuruluş amaçlarını olumsuz etkilemeyeceği, dolayısıyla tüzel kişiliklerin menfaatini ihlal etmeyeceği sonucuna varılmıştır. Bu kararda, Baroların hukukun üstünlüğünü koruma ve sağlama görevleri tamamen göz ardı edilmiştir.

Barolar açısından menfaat kavramının olması gerektiği gibi geniş yorumladığı yakın tarihli bir Danıştay kararına da yer vermek isteriz. Danıştay İDDK, Sivil Havacılık Genel Müdürlüğü'nün 19.11.2015 tarihinde sosyal medya üzerinden yayınladı̆̆ı, uçak altı kilitli bagajların

sinde hukukun üstünlüğünü, insan haklarını savunmak ve korumak gibi bir işlev yüklenmesi nedeniyle diğer meslek örgütlerinden farklı bir konuma sahip olduğu açıktır." Danıştay IDDK'nın 10.12.2009 tarih ve Y.D. İtiraz No: 2009/1015 sayılı kararı için bkz. http://www.memurlar.net/haber/155751/, (09.01.2021).

“...davacı Baro'nun doğrudan, kişisel ve meşru bir menfaatinin olmadı̆̆ı, dolayısıyla bu konuda dava açma ehliyetinin bulunmadığı gerekçesiyle, davanın ehliyet yönünden reddine karar verilmiştir." Danıştay İDDK'nın 22.10.2009 tarih ve E.2006/4705, K.2009/1863 sayılı kararı, (Kazanc1).

103 Rize İdare Mahkemesi'nin 20.09.2016 tarih ve E.2015/470 K.2016/485 sayılı kararı, (Kişisel Arşiv). 
gerektiğinde güvenlik birimlerince kilitlerinin kırılarak açılmak zorunda kalındığı ve içine not konulduğu, uçak altı bagajları güvenlik sebebiyle güvenlik birimlerince incelenebileceğinden, bagajların kilitlenmemesi gerektiğinin duyurulmasına ilişkin işlemin iptali istemiyle temyizen incelediği davada ${ }^{104}$, menfaatin özelliklerinden bahsettikten sonra, menfaatin kişisel olmasının, idari işlemin mutlaka davacı hakkında tesis edilmiş olması sonucunu doğurmadığını belirtmiştir. Kurula göre, sözü edilen menfaat ilişkisinin varlığı ve sınırları davacının gerçek kişi, tüzel kişi, belde sakini olması gibi çeşitli hususlar dikkate alınmak suretiyle ve her olayda yargı yerince uyuşmazlığın niteliği göz önünde tutularak belirlenmelidir. Davacının kamu kurumu niteliğinde meslek kuruluşu olan bir Baro olduğu ve bu sıfatı gereği bu kurumların kuruluş kanunlarında gösterilen amaçlar doğrultusunda dava açma ehliyetinin bulunduğu belirtilmiştir. Öte yandan baroların; mesleki bir örgüt olmanın ötesinde hukukun üstünlüğünü, insan haklarını savunmak ve korumak gibi bir işlev yüklenmesi nedeniyle diğer meslek örgütlerinden farklı bir konuma sahip olduğu vurgulanmıştır. Hukukun üstünlügünü koruma görevi ve yükümlülüğü bulunan davacı Baro Başkanlığının, dava konusu düzenlemenin niteliği gereği dava açma ehliyeti bulunmakta olup, işin esasının incelenmesi suretiyle bir karar verilmesi gerektiği sonucuna varıldığından, davanın ehliyet yönünden reddine ilişkin Daire kararında hukuki isabet görülmemiştir.

Kamu kurumu niteliğindeki meslek kuruluşları ile ilgili olarak Danıştay, TMMOB İnşaat Mühendisleri Odası'nın İstanbul Büyükşehir Belediyesi'nin Ümraniye Dudullu Kavşağı Köprü Kavşak ve Yan Yolları Düzenlemesi İnşaatı İhalesinin iptali istemiyle açtı̆̆ davanın temyiz incelemesinde, ilk derece mahkemesinin aksine menfaat ihlali bulundu-

104 “Danıştay kararları ışı̆̆ında konuya bakıldığında; Avukatlık Kanunu'nda yapılan değişiklikten sonra açılan davalarda dava açma ehliyetinin bulunup bulunmadığı saptanırken, iptal davasının genel amacının yanı sıra dava konusu idari işlemin, hukukun üstünlüğünü, hukuk devleti ilkesini, genel kamu yararı, Anayasa ile koruma altına alınan eşitlik, kişinin dokunulmazlığı, özel hayatın gizliliği, kanunsuz suç ve ceza olamayacağı gibi temel insan haklarını ihlal edip etmediğine ve yargı kararlarının uygulanmaması veya geçersiz kılınması gibi hukuk devleti ilkesini zedeleyen bir durumun olayda söz konusu olup olmadığına bakılarak menfaat ilgisinin olaya özgü, ancak daha geniş yorumlandığı görülmektedir." Danıştay İDDK'nın 23.12.2020 tarih ve E.2020/1033, K.2020/3395 sayılı kararı, (Legalbank). 
ğuna hükmetmiş ve ilk derece mahkemesinin ehliyet yönünden reddine ilişkin hükmünü bozmuştur. ${ }^{105}$ Danıştay kararında, dava konusu, davacı Odanın meslek sınıfına ait bir iş olan yapım işinin ihalesi olduğundan ve ihaleye çıkarma işleminin ilan edilmemesi mevzuata aykırı olduğundan; meslek kurallarını, şehircilik ilkelerini ve nihayetinde kamu yararını ihlal ettiği iddialarıyla iptal davasının açıldığı anlaşıldığından, davacı Odanın dava konusu işlem nedeniyle menfaatinin ihlale uğradığı sonucuna varılmıştır.

Siyasi partilerin, parti tüzüklerinde yer alan amaçlar doğrultusunda dava ehliyetine sahip oldukları söylenebilir. 2820 sayılı Siyasi Partiler Kanunu madde 15/3'te dava açma yetkisi, genel başkana veya parti tüzügünün başkanının yerine bu yetkileri kullanmak üzere gösterdiği parti merciine verilmiştir. Hanönü Orman İşletme Müdürlüğü'nün kapatılmasını içeren bir Bakanlar Kurulu kararının ilgili kısmının iptali talebiyle açılan davada ${ }^{106}$, CHP Hanönü ilçe temsilciliğinin dava ehliyeti olmadığına hükmedilmiştir. Karara göre, tüzükte dava açma yetkisi genel sekretere verilmiştir ve ilçe temsilciliği yetkisizliği nedeniyle dava açamamaktadır. Dava konusu işlemle siyasi parti arasında bir menfaat alakasızlığından bahsedilmemiş, dava açma yetkisinin genel sekretere verildiği vurgulanmıştır. CHP Tüzüğünün 36. maddesinde, partiyi genel başkanın temsil edeceği, genel başkanın yokluğunda ise genel başkan yardımcılarından birini görevlendireceği düzenlenmiştir. 39. maddede ise genel sekreterin, genel başkanlık adına partiyi mahkemelerde temsil edeceği, yokluğunda genel başkanın onayıyla görevlendirilecek bir genel sekreter yardımcısının kendisine vekâlet edeceği düzenlenmiştir. İlgili hükme göre, parti adına dava açma ve davaya taraf olma yetkisi

105 “Danıştay içtihatlarında, ihaleye katılmayan ve ihale ile herhangi bir ilgisi kurulamayan gerçek ve tüzel kişilerin ihaleden dolayı menfaatinin ihlal edilmediği, dolayısıyla bunların ihale işlemlerinin iptali istemiyle açtığı davalarda, kural olarak, dava açma ehliyetinin bulunmadığ iptali istemiyle açılan davada, davacının kamu kurumu niteliğindeki meslek kuruluşu olması halinde, dava açma ehliyeti konusunun Danıştay kararlarında, davacının faaliyet alanı ile ihale işlemi arasında bir menfaat ilgisi kurulup kurulamayacağ1 yönünden incelendiği anlaşılmaktadır." Danıştay IDDK'nın 18.06.2009 tarih ve E.2009/1356, K.2009/1679 sayılı kararı, (Kazanc1).

Danıştay IDDK'nın 11.04.2008 tarih ve E.2007/2206, K.2008/1184 sayılı kararı, (Kazanc1). 
genel sekretere ait olduğundan, CHP Hanönü İlçe Başkanlığını temsilen ilçe başkanınca dava açılmasında sübjektif ehliyet şartı olan menfaat ihlali gerçekleşmemiştir. Parti tüzüğünde dava açma ehliyeti belli kişilere verildiğinden bu durumun göz önünde bulundurulması gerekmektedir. Söz konusu olayda mesele partinin dava ehliyeti değil, dava açma konusunda yetkilendirilmemiş kişinin partiyi temsil edemeyecek oluşudur. Kararda, menfaat ihlali kavramının yorumlanması bakımından herhangi bir sorun söz konusu değildir.

Bir başka kararda ise, parti ilçe teşkilatının imar planı yapılmasına ilişkin işlemle kişisel bir menfaat ilişkisi kurulamamıştır. ${ }^{107}$ Uyuşmazlığa konu imar planının iptali istemiyle açlan davada, faaliyet konusu itibariyle şehirleşme ve imarla ilgisi bulunmayan parti ilçe teşkilatının, imar planı hazırlanmasına ilişkin işleme karşı sübjektif dava ehliyetinin bulunmadığı, dolayısıyla menfaat ihlalinin söz konusu olmadığı sonucuna varıldığından, temyiz merci olan Danıştay İDDK, idare mahkemesince davanın esasının incelenmesi suretiyle verilen kararın isabetli olmadığına hükmetmiştir. Olayda, sübjektif dava ehliyeti olan menfaat ihlali gerçekleşmediğinden davanın reddedilmesi gerektiği belirtmiştir.

Toplulukların iptal davası açma ehliyetine sahip olup olmadıkları değerlendirilirken, ilgili kararlara göre, esas alınacak birtakım ölçütler vardır. İlk ölçüt, topluluğun hukuka uygun olarak kurulmuş olmasıdır. Hukuka uygun biçimde kurulmayan dernekler, sendikalar ve benzeri kuruluşlar tüzel kişilik kazanamadıklarından ve bu nedenle hak ehliyeti sahibi olamadıklarından dava ehliyetleri de olmayacaktır. Sübjektif dava ehliyetinin önkoşulu objektif dava ehliyetidir. İkinci ölçüt, üyelerine yönelik işlemlere karşı dava açabileceğine ilişkin topluluk tüzüklerinde açık bir düzenlemenin yer almasıdır. Son ölçüt ise, işlemin kendi faaliyet alanlarıyla ilgili olmasıdır. Nihayetinde toplulukların, dayandıkları mevzuatta öngörülen amaçları gerçekleştirmek adına açtıkları davalar$\mathrm{da}$, dava ehliyetlerinin geniş yorumlanması gerekir.

107 Danıştay İDDK'nın 19.10.2001 tarih ve E.2000/954, K.2001/683 sayılı kararı, (KazanC1). 


\section{Platformların Menfaat Grubu Oluşturma Sorunsalı}

Son dönemlerde toplantı ve gösteri yürüyüşleri, toplumsal eylemler ve özellikle Gezi eylemleri sonrasında "platform" kavramıla sık karşılaşmaktayız. Gezi eylemleri108 sırasında yapılan gösteriler, düzenlenen forumlar Taksim Platformu ${ }^{109}$ gibi çeşitli platformların öncülüğünde gerçekleştirilmiştir. Bu çerçevede, platformların hukuki niteliğine bakarak, yapılan idari işlemler sebebiyle menfaatlerinin ihlal edildiğini söylemek mümkün müdür, bu başlıkta bu soruya yanıt aranacaktır.

Platformların hukuki niteliğine ilişkin değerlendirme yapabilmek için öncelikle hukuki bir tanımlamasının yapılıp yapılmadığını tespit etmek gerekir. Dernekler Kanunu md. 2/f'de platformun tanımı yapılmaktadır. Maddeye göre, plâtform, derneklerin ortak bir amacı gerçekleştirmek üzere kendi aralarında ya da vakıf, sendika ve benzeri sivil toplum kuruluşlarıyla aralarında oluşturdukları, girişim, hareket vb. isimlere sahip "tüzel kişiliği bulunmayan" geçici nitelikteki birlikteliklerini ifade eder.

Dernekler Kanunu'nun "Platform Oluşturma" başlıklı 25. maddesinde ve Dernekler Yönetmeliği'nin "Platformlar" başlıklı 94. maddesinde; derneklerin, amaçlarıyla ilgili olan ve kanunlarla yasaklanmayan alanlarda, diğer başka dernek, vakıf, sendika vb. sivil toplum kuruluşlarıyla ortak bir amacı gerçekleştirmek üzere platformlar oluşturabileceği düzenlenmiştir. Platformların oluşturulabilmeleri için derneklerin yetkili organları tarafından alınacak kararlarda, derneği temsil etmek üzere görevlendirilecek kişi veya kişilerin belirlenmesi gerekir. Platform, temsilciler tarafından düzenlenecek bir mutabakat tutanağı ile faaliyete başlayabilir. Mutabakat tutanağında, platformun oluşturulma amacı, çalışmaların yürütüleceği yerleşim yeri ile yönetim grubu üyeleri ve koordinatörünün isimleri belirtilir.

108 İstanbul Büyükşehir Belediyesi'nin “Taksim Yayalaştırma Projesi” kapsamında Gezi parkının yerine Topçu Kışlası görünümünde bir alışveriş merkezinin yapılması kararı karşısında vatandaşların tepki göstermesiyle başlayan süreç, kısa zamanda büyümüş ve ülkenin her yerinde eylemler yapılmaya başlanmıştır. 27.05.2013 tarihinde ağaçların kesilmesini önlemek amacıyla yaklaşık 50 kişi tarafından gezi parkına çadırlar kurulması ile başlamıştır.

109 Taksim Platformunu oluşturan bileşenler için bkz. http://taksimdayanisma.org/bilesenler, (09.01.2021). 
Dernekler Kanunu'nun 2. maddesinde platformların tüzel kişiliği haiz olmadıkları açıkça belirtilmiştir. Tüzel kişiliği olmadığından platformların, resmi makamlar önünde işlem yapma, talepte bulunma hakları yoktur. ${ }^{110}$ Çünkü tüzel kişiliğe sahip olmayan platformların hak ehliyeti bulunmamaktadır. ${ }^{111}$ İngiliz ve Fransız hukukunda kişilik sahibi olmak dava ehliyeti bakımından aranan bir şart değildir. ${ }^{12}$ Ancak bizim hukukumuzda hak ehliyetinin doğması için tüzel kişiliğe sahip olmaları gerekir. ${ }^{113}$ Platformların tüzel kişiliğinin bulunmuyor oluşu, platformların objektif ehliyete, dolayısıyla davaya taraf olma ehliyetine sahip olmadıkları anlamına gelir. Objektif ehliyete sahip olmadıklarından, platformların sübjektif ehliyet değerlendirmesini yapmaya gerek yoktur.

Platformlarca hukuka aykırı olduğu ve iptal edilmesi gerektiği düşünülen işlemler aleyhine, platformları oluşturan ve tüzel kişilik sahibi olan dernekler, vakıflar, sendikalar ya da siyasi partiler gibi sivil toplum kuruluşlarının dava açma ehliyetinden söz etmek gerekir. Ve bu gibi toplulukların sübjektif ehliyetlerini de geniş yorumlamak gerekir. Örneğin, İstanbul Büyükşehir Belediyesi'ne ait "Taksim Yayalaştırma Projesi"

110 "Platform olarak düzenlenen etkinliklerde "platform" adının kullanılması ve basına ya da kamuoyuna yönelik çağrıların bu şekilde yapılması mümkündür. Ancak, platformun tüzel kişiliği bulunmadığı için, örneğin resmî makamlara yönelik izin gerektiren faaliyetlerde, platformu oluşturan sivil toplum kuruluşlarının bizzat kendilerinin imzası ile resmî işlemler yürütülebilir." YALÇIN, Abbas/ÖZ, Yasemin, Sivil Toplum Kuruluşları İçin Hukuk Rehberi, Odak Ofset Matbaacılık, 2. Baskı, Ankara, 2011, s. 242, https://www.stgm.org.tr/sites/default/files/2020-08/siviltoplum-orgutleri-icin-hukuk-rehberi.pdf, (10.01.2021).

111 SEROZAN, Rona, Medeni Hukuk, Vedat Kitapçılık, İstanbul, 2013, s. 503.

112 Örneğin, Özay, Amerikan Federal Yüksek Mahkemesi'nin menfaat kavramını oldukça geniş yorumladığı bir kararından bahsetmektedir. Kararda, bir akarsu üzerine inşa edilecek elektrik santrali için verilmiş bulunan izin konusunda kendilerinin görüşü alınmadığı için yargı yoluna başvuran sanatçı, aydın, bilim adamı gibi kişilerin oluşturdukları "fiili dernek" tarafından yapılan başvuruyu kabul etmiştir. ÖZAY, s. 152-153.

113 “Tüzelkişiler, hukuk düzeninin kişilik tanıdığı örgütlerdir. Bunların, doğrudan muhatabı olmadıkları birel işlemlere karşı iptal davası açması özel olarak ele alınmalıdır. İngiliz ve Fransız hukukunda, bu konu, tüzelkişilikleri de aşar şekilde, tüzelkişiliğe sahip olmayan örgütlenmeleri de kapsamak üzere kolektiviteler üzerinden ele alınmakta, sadece çıkarların takibi olarak değil, bireylerin örgütlenerek yönetime katılma niyetinin bir aracı olarak düşünülmektedir." KARAHANOĞULLARI, "İlgi Bağ1 http://80.251.40.59/politics.ankara.edu.tr/karahan/makale/ilgibagi.htm. 
kapsamında Gezi parkının yerine Topçu Kışlası görünümünde bir alışveriş merkezinin yapılması kararına karşı Taksim Platformu'nda yer alan "Taksim Gezi Parkı Koruma ve Güzelleştirme Derneği” tarafından dava açılmıştır. ${ }^{114}$ Dava, İstanbul 6. İdare mahkemesince ehliyet yönünden kabul edilmiş, ancak dava konusu işlemde hukuki isabetsizlik görülmediğinden dava reddedilmiştir.

\section{SONUÇ}

İptal davasının sübjektif ehliyet koşulu olan menfaat ihlali kavra$\mathrm{m}$, geniş yorumlandığında iptal davasının uygulanma alanını genişleten bir kavramdır. İptal davasının uygulama alanının genişlemesi ise, Anayasa'nın 2. maddesinde ifadesini bulan hukuk devleti ilkesini gerçekleştirmenin en etkili yoludur. Dolayısıyla yargı yerleri tarafından menfaat kavramının geniş yorumlanmasıyla hukuk devleti ilkesinin gerçekleştirilmesine hizmet edilecektir.

İptal davası açabilmek için İYUK'un 2. maddesinde aranan menfaat ihlali şartının kapsamı yargı yerlerinin değerlendirmeleri ile belirlenmektedir. Somut olaylara göre yargı yerleri davacının menfaatinin ihlal edilip edilmediğine hükmetmektedir. Menfaat ihlali şartı, aslında iptal davası açabilmeyi sınırlandırmaktadır. İptal davasında amaç, idarenin hukuka aykırı işlemlerinin iptal edilerek hukuk âleminden çıkarılmasını sağlamak olduğundan ve bu durum herkesin menfaatini ilgilendirdiğinden dava açabilme ehliyetinin sınırlandırılmaması gerekir. Ancak herkesin dava açabilmesi halinde, idari yargi yerleri altından kalkamayacakları bir iş yüküyle karşı karşıya kalacaktır. Öte yandan ciddi, makul ve güncel bir menfaati ihlal edilsin edilmesin herkesin dava açması, idarenin yargısal denetimin sağlıklı işlemesine engel olacaktır. İdarenin herkes tarafından dava tehdidi altında kalması, idarenin işleyişini ve kamu hizmetlerinin görülmesini aksatacaktır. Bu nedenlerle, hukuk devleti ilkesine zarar vermeden, dava açma ehliyetine makul ölçülerde sinırlama getirilmesinde hukuka aykırılık bulunmamaktadır.

Sübjektif dava açma ehliyetinin var olup olmadığını değerlendirebilmek için içtihatlarda menfaat kavramı bakımından bazı ölçütlerin

\footnotetext{
114 https://t24.com.tr/haber/gezi-parkina-topcu-kislasi-projesine-iptal-davasinadanistaydan-ret,340357, (14.01.2021).
} 
esas alındığ1 görülmektedir. Ehliyetin varlığı için menfaatin meşru, güncel ve kişisel olması aranmaktadır. Söz konusu ölçütleri içeren bir menfaate sahip olan kişinin, ilgili işlemin iptalini isteyebileceği kabul edilmektedir. Aranan ölçütler, hak kavramından daha geniş bir koruma alanını ifade eden menfaat kavramı ile bağdaşmaktadır. Bu ölçütlerden meşruluk ve güncellik kolay belirlenebilir olmakla birlikte, kişisellik ölçütü kolay belirlenebilir değildir. Yarg1 yerlerinin değerlendirmelerinde, menfaat kavramı kişisellik ölçütü çerçevesinde geniş ya da dar yorumlanabilmektedir. Kişisellik ölçütü, işlemin herkesle alakasını kurmamakla birlikte, menfaati zarara uğrayan kişiler ya da topluluklar bakımından geniş yorumlanmalıdır. Menfaat kavramı bu ölçüt bakımından esnetilmelidir.

Menfaat kavramının yargı yerlerince dar yorumlanması sonucu, adil yargılanma hakkı kapsamındaki mahkemeye erişim hakkının ihlal edildiği gerekçesiyle Anayasa Mahkemesi'ne başvurular yapılmıştır. Anayasa Mahkemesi, bu yöndeki kararlarında, menfaat kavramının somut olayın nitelikleri de göz önünde bulundurularak geniş yorumlanması ve kamu yararı ile bireysel menfaat arasında adil bir denge kurularak kişinin menfaatinin bulunup bulunmadığının belirlenmesi gerektiğini vurgulamıştır. Mahkemenin değerlendirmelerinden çıkardığımız sonuç, idari yargıda sübjektif ehliyet koşulu olan menfaat ihlali kavramının yorumlanmasında kişilerin hak arama özgürlüklerinin kısıtlanması sonucu doğurup doğurmayacağının dikkate ele alınması gerektiğidir. İdari yargı alanında iptal davası açabilmek için menfaati ihlalinin varlığının yeterli sayılması, hak arama özgürlüğü lehine bir düzenlemedir. Bu çerçevede, menfaat konusundaki sınırları aşmayan geniş yorum, mahkemeye erişim hakkını ve dolayısıyla adil yargılanma hakkını koruyacaktır.

Sonuç olarak, menfaat kavramı, kişisel hak ihlaline varacak kadar dar ya da idarenin denetimini zorlaştıracak, üstesinden gelinmez hale getirecek kadar geniş yorumlanmamalıdır. Hukuki kişilik sahibi olmayan topluluklar bakımından menfaat kavramını geniş yorumlama tartışması yapmak elbette mümkün olmayacaktır. İncelendiği üzere, platformların kişiliğe sahip olmamaları, menfaat tartışmasını objektif ehliyet konusuyla sınırlamaktadır. Objektif ehliyet koşulunu sağlayamayan 
1122 | Arş. Gör. Burcu ERDiNÇ

platformlar bakımından sübjektif ehliyet tartışması yapmak mümkün olmayacaktır. 


\section{KAYNAKLAR}

AKYILMAZ, Bahtiyar/SEZGİNER, Murat/KAYA, Cemil, Türk İdare Hukuku, 12. Baskı, Savaş Yayınevi, Ankara, Eylül 2020. (İdare) AKYILMAZ, Bahtiyar/SEZGİNER, Murat/KAYA, Cemil, Türk İdari Yargılama Hukuku, 4. Baskı, Savaş Yayınevi, Ankara, Eylül 2020. (Yarg1)

AKYÜREK, Akman, “Danıştay Kararlarında İptal Davalarının Menfaat İhlali Koşulunun Kişisellik Unsuru", Danıştay Dergisi, Sayı 8081 , s. 29-45.

ALAN, Nuri, "İptal Davasının Ön ve Esastan Kabul Şartları”, Danıştay Dergisi, Sayı 50-51, 1983.

ALTUNDİs, Mehmet, "İdari Yargıda Dava Açma Ehliyeti”, Türkiye Barolar Birliği Dergisi, 2007 (69), s. 339-376.

ATAY, Ender Ethem, Hukuk Başlangıcı, Gazi Kitabevi, 8. Baskı, Ankara, 2020.

ATAY, Ethem Ender, İdare Hukuku, Turhan Kitabevi, 6. Baskı, Ankara, 2018. (İdare)

BİLGİN, Hüseyin, “Danıştay Kararları Işı̆̆ında İptal Davalarında Menfaatin Güncel Olması", Terazi Hukuk Dergisi, Sayı 30, 2009, s. 137-150.

COŞKUN, Şenol, “İptal Davalarında Menfaat İhlali Koşulu”, Terazi Hukuk Dergisi, Y1l 5, Say1 46, 2010, s. 139-158.

ÇAĞLAYAN, Ramazan, İdari Yargılama Hukuku, Seçkin Yayınları, 11. Bask1, 2019. (Yarg1)

ÇAĞLAYAN, Ramazan, İdare Hukuku Dersleri, Adalet Yayınları, 7. Bask1, 2019. (İdare)

CHAPUS, René, Droit du Contentieux Administratif, Paris, 2002.

ÇELİKKOL, Hüseyin, "İdari Yargıda Ehliyet ve Husumet”, Adalet Dergisi, Yıl 76, Sayı 3, Mayıs- Haziran 1985, s. 749-770.

Danıştay Altıncı Daire Kararları (1965-1977), Danıştay Tasnif ve Yayın Bürosu Yayınları, 1979.

DURAN, Lütfi, İdare Hukuku Ders Notları, İstanbul Üniversitesi Yayınları No: 2956, İstanbul, 1982. 
EREN, Fikret, Borçlar Hukuku Genel Hükümler, Yetkin Yayınları, Ankara, 2012.

ERKUT, Celal, İptal Davasının Konusunu Oluşturma Bakımından İdari İşlemin Kimliği, Danıştay Başkanlığı Yayını, Ankara, 1990.

ERTÜRK, Ahmet Çetin, Fransızca-Türkçe Türkçe-Fransızca Bilge Büyük Sözlük, Öz-El Matbaası, Ankara, 2002.

GÖÇGÜN, Faruk, İptal Davasında Sübjektif Ehliyet Koşulu Olarak Kişisel Menfaat Unsuru, Gazi Üniversitesi Sosyal Bilimler Enstitüsü, Yüksek Lisans Tezi, 2016.

GÖKALP ALICA, Süheyla Suzan, “Çevrenin Korunmasına İlişkin İptal Davalarında Kişisel Menfaat Kavramı", Türkiye Barolar Birliği Dergisi, 2018 (139), s. 165-220.

GÖZÜBÜYÜK, Şeref, Yönetsel Yarg1, Turhan Kitapevi, Ankara, Ekim 2010.

GÖZÜBÜYÜK, Şeref/TAN, Turgut, İdare Hukuku Genel Esaslar Cilt I, Turhan Kitabevi, Ankara, 2013.

GÜNDAY, Metin, İdare Hukuku, İmaj Yayınevi, 10. Baskı, Ankara, 2013.

KAPLAN, Gürsel, “İdari Yargıda Ehliyet ve Husumet Sorunu Üzerine Düşünceler", Maltepe Üniversitesi Hukuk Fakültesi Dergisi, 2008/2, s. 23-54.

KARAHANOĞULLARI, Onur, “Birel İşleme Karşı Açılan İptal Davalarında İlgi Bağı Sorunu", Ankara Üniversitesi Siyasal Bilgiler Fakültesi Dergisi, Cilt 62, Sayı 3, s. 201-233, http://80.251.40.59/politics.ankara.edu.tr/karahan/makale/ilgiba gi.htm, (09.01.2021).

KARAHANOĞULLARI, Onur, Türkiye'de İdari Yarg1 Tarihi, Turhan Kitabevi, Ankara, 2005.

KARAHANOĞULLARI, Onur, “İdarenin Yargısal Denetimine Yönelik Anayasa Değişiklikleri ve Takdir Yetkisinin Yargısal Denetimi", Mülkiye Dergisi, Cilt 35, Sayı 270, 2011, s. 43-64.

KAYA, Cemil, İdarenin Takdir Yetkisi ve Yargisal Denetimi, XII Levha Yayınları, İstanbul, 2011. 
KAYA, Cemil, “İptal Davalarında (Kişisel) Menfaat İhlalinin Genişlemesi: İktisadi Rekabet", İstanbul Üniversitesi Hukuk Fakültesi Dergisi, Cilt LXVI, Sayı 2, 2008, s. 273-284.

KAYA, Cemil, “Danıştay Kararları Işığında İptal Davaları Açısından Sendikaların Sübjektif Dava Ehliyeti", Prof. Dr. Ali Naim İnan'a Armağan, Ankara, 2009, s. 1215-1250.

KOÇAK, Mustafa, “Hukuk Devleti Kavramı Açısından İptal Davasında Menfaat İhlali ve Hak İhlali Koşulu", Hukuk Araştırmaları Dergisi, Cilt 10, Sayı 1-3, 1996, s. 117-147.

OĞUZMAN, Kemal/BARLAS, Nami, Medeni Hukuk (Giriş-KaynaklarTemel Kavramlar), Vedat Kitapçllık, İstanbul, 2013.

ONAR, Sıddık Sami, İdare Hukukunun Umumi Esasları (Cilt III), İsmail Akgün Matbaası, 3. Bası, İstanbul, 1966.

ÖZAY, İl Han, Günışığında Yönetim II Yargısal Korunma, On İki Levha Kitabevi, İstanbul, 2010.

ÖZDEK, Yasemin, "İptal Davasında Menfaat Koşulu”, Amme İdaresi Dergisi, Cilt 24, Sayı 1, 1991, s. 99-115.

ÖZYÖRÜK, Mukbil, İdare Hukuku Ders Notları, Ankara, 1977.

SEZGINER, Murat, İptal Davasının Uygulama Alanı Bakımından Ayr1labilir İşlem Kuramı, Yetkin Yayınları, Ankara, 2000.

YALÇIN, Abbas/ÖZ, Yasemin, Sivil Toplum Kuruluşları İçin Hukuk Rehberi, Odak Ofset Matbaacilık, Ankara, Haziran 2011, https://www.stgm.org.tr/sites/default/files/2020-08/siviltoplum-orgutleri-icin-hukuk-rehberi.pdf, (10.01.2021).

YAYLA, Yıldızhan, İdare Hukuku, Beta Yayınları, İstanbul, 2009.

YILMAZ, Dilşat, "Alman İdari Yargılama Hukukunda İptal Davası", Gazi Üniversitesi Hukuk Fakültesi Dergisi, Cilt XIII, Sayı 1-2, 2009, s. 303-320.

YÜCEL, Yonca, “Hak ve Menfaatler Üzerine Bir İnceleme”, Türkiye Barolar Birliği Dergisi, 2010 (91), s. 335-357.

YÜCESOY, Ayşe Aslı, İdari Yargılama Hukukunda İptal Davalarında Menfaat, Seçkin Yayınları, Ankara, 2016. 